\title{
Scale and structure of time-averaging (age mixing) in terrestrial gastropod assemblages from Quaternary eolian deposits of the eastern Canary Islands
}

\author{
Yurena Yanes $^{\mathrm{a}, *}$, Michał Kowalewski ${ }^{\mathrm{a}}$, José Eugenio Ortiz ${ }^{\mathrm{b}}$, Carolina Castillo ${ }^{\mathrm{c}}$, \\ Trinidad de Torres ${ }^{\mathrm{b}}$, Julio de la Nuez ${ }^{\mathrm{d}}$ \\ ${ }^{a}$ Department of Geosciences, Virginia Polytechnic Institute and State University, 4044 Derring Hall, Blacksburg, VA, 24061, US \\ ${ }^{\mathrm{b}}$ Biomolecular Stratigraphy Laboratory, Escuela Técnica Superior de Ingenieros de Minas de Madrid, C/ Ríos Rosas 21, 28003, Madrid, Spain \\ ' Departamento de Biología Animal, Facultad de Biología, Universidad de La Laguna, Avda. Astrofísico Fco. Sánchez, s/n. 38206, \\ La Laguna, Tenerife, Canary Islands, Spain \\ 'Departamento de Edafologia y Geología, Facultad de Biología, Universidad de La Laguna, Avda. Astrofísico Fco. Sánchez, \\ s/n. 38206, La Laguna, Tenerife, Canary Islands, Spain
}

\begin{abstract}
Quantitative estimates of time-averaging (age mixing) in gastropod shell accumulations from Quaternary (the late Pleistocene and Holocene) eolian deposits of Canary Islands were obtained by direct dating of individual gastropods obtained from exceptionally well-preserved dune and paleosol shell assemblages. A total of 203 shells of the gastropods Theba geminata and T. arinagae, representing 44 samples (=stratigraphic horizons) from 14 sections, were dated using amino acid (isoleucine) epimerization ratios calibrated with 12 radiocarbon dates. Most samples reveal a substantial variation in shell age that exceeds the error that could be generated by dating imprecision, with the mean within-sample shell age range of 6670 years and the mean standard deviation of 2920 years. Even the most conservative approach (Monte Carlo simulations with a non-sequential Bonferroni correction) indicates that at least $25 \%$ of samples must have undergone substantial time-averaging (e.g., age variations within those samples cannot be explained by dating imprecision alone). Samples vary in shell age structure, including both left-skewed (17 out of 44) and right-skewed distributions (26 out of 44 ) as well as age distributions with a highly variable kurtosis. Dispersion and shape of age distributions of samples do not show any notable correlation with the stratigraphic age of samples, suggesting that the structure and scale of temporal mixing is time invariant. The statistically significant multi-millennial time-averaging observed here is consistent with previous studies of shell accumulations from various depositional settings and reinforces the importance of dating numerous specimens per horizon in geochronological studies. Unlike in the case of marine samples, typified by right-skewed age distributions (attributed to an exponential-like shell loss from older age classes), many of the samples analyzed here displayed leftskewed distributions, suggestive of different dynamics of age mixing in marine versus terrestrial shell accumulations.
\end{abstract}




\section{Introduction}

Due to time-averaging (age mixing), fossils collected from a single stratigraphic layer tend to vary in age over multi-centennial to multi-millennial timescales, and many individual specimens may be hundreds or even thousands of years older than the deposits in which they are contained (for recent reviews see Kidwell, 1998; Behrensmeyer et al., 2000; Kowalewski and Bambach, 2003). In late Quaternary deposits, where individual fossils can be dated with a sufficient precision, multiple dating projects conducted recently suggest that time-averaging is a prevailing phenomenon for shelly fossil (e.g., gastropods, bivalves, brachiopods, etc.) from diverse depositional settings, including marine (e.g., Flessa et al., 1993; Wehmiller et al., 1995; Meldahl et al., 1997; Kowalewski et al., 1998; Carroll et al., 2003; Fujiwara et al., 2004; Kidwell et al., 2005; but see Powell et al., 2006), lacustrine (Cohen, 1989), and terrestrial (e.g., Goodfriend, 1989; Goodfriend and Mitterer, 1993; Goodfriend et al., 1996) systems. The pervasive presence of time-averaging is not surprising given that physical and/or biological processes that mix non-contemporaneous shells (e.g., erosional reworking, lateral sediment transport, bioturbation, etc.) affect nearly all depositional settings.

Time-averaging may limit our ability to study ancient ecological and environmental patterns (e.g., Kowalewski, 1996; Goodwin et al., 2004), not only because it reduces the resolution of the fossil record, but also because averaging can generate false patterns (e.g., Kowalewski, 1996). As important, because of age mixing, geochronologic estimates derived by numerical dating of shells may overestimate the actual age of stratigraphic units that are being dated (e.g., Goodfriend, 1989). Consequently, evaluating the magnitude of timeaveraging is essential for both reconstructing past environments and ecological conditions as well as assessing geochronological inaccuracies inherent to dated specimens from time-averaged accumulations.

The scale of time-averaging is not easily estimated in the fossil record and may vary across depositional environments (e.g., Kidwell et al., 2005) or taxa (e.g., Kowalewski, 1996). While several indirect techniques may be attempted to estimate the scale of time-averaging (e.g., Cummins et al., 1986; Flessa, 1993; Cummins, 1994; Goodwin et al., 2004), direct estimates based on numerical dating of individual fossils appear to be the most reliable quantitative strategy (see Flessa, 1993; Kowalewski and Bambach, 2003). In particular, the amino acid racemization/epimerization (AAR) esti- mates calibrated against radiocarbon $\left({ }^{14} \mathrm{C}\right)$ have been established in recent years as a successful strategy for quantifying time-averaging by allowing for affordable, precise and accurate dating of large numbers of specimens from late Quaternary deposits (e.g., Kowalewski et al., 1998; Carroll et al., 2003; Kidwell et al., 2005; Barbour Wood et al., 2006).

To estimate the magnitude of time-averaging, we have used a combination of amino acid and radiocarbon dating techniques. Radiocarbon-calibrated amino acid racemization/epimerization rates are among the most efficient techniques for dating individual Quaternary shells (e.g., Goodfriend, 1987; Kowalewski et al., 1998; Carroll et al., 2003; Kidwell et al., 2005; Ortiz et al., 2006; and numerous references therein). The shell age estimates reported in this study are thus methodologically comparable to many other geochronological datasets published previously (e.g., Goodfriend, 1987, 1989, 1992a,b; Hearty et al., 1992; Hearty, 2003; Cook et al., 1993; Engel et al., 1994; Preece and Day, 1994; Goodfriend et al., 1994, 1996; Hearty, 1997; Meyrick and Preece, 2001; Brooke et al., 2003a,b; Pigati et al., 2004; Hearty et al., 2004).

The method is based on the fact that organisms produce only L-amino acids, which subsequently racemize (epimerize) into D-amino acids. Consequently, the $\mathrm{D} / \mathrm{L}$ ratio increases with time until an equilibrium $(\mathrm{D} / \mathrm{L}=1$, but $\mathrm{D} / \mathrm{L}=1.3$ for isoleucine) is reached. The racemization/epimerization process is a first-order-reversible chemical reaction, which is taxon and temperature-dependent.

The land snail shells are one of the better targets for amino acid dating because their non-porous shells are unlikely to suffer notable contamination by soil-derived organic matter (Hare and Mitterer, 1968). In addition, their subaerial habitat makes them less vulnerable to protein hydrolysis when comparing with aquatic shellfish (Goodfriend, 1987).

Here, we present quantitative estimates of time-averaging in land snail assemblages found in Quaternary eolian deposits from the Canary Islands, Spain. We have applied a combination of AAR and radiocarbon to date numerous shells of helicid land snails from multiple dune and paleosol levels. The approach provides an opportunity to estimate directly the scale and structure of time averaging for numerous horizons and multiple section representing Late Quaternary terrestrial environments that span the last 50,000 years. We augment the analysis by applying computer-intensive statistical approaches, which serve to evaluate the significance of time-averaging in the context of age imprecision inherent to the applied dating techniques. 


\section{Study area, materials, and methods}

\subsection{Geographical setting}

Thick sequences of Quaternary sediments, which consist of alterations of paleosols and eolian sand deposits, crop out on the eastern islands of the Canary Archipelago (Fig. 1). These sediments have been attributed to alternating humid and arid periods during the Quaternary (Meco et al., 1997; De La Nuez et al., 1997; Castillo et al., 2002) and preserve a rich fossil record of vertebrates and invertebrates. Among the invertebrates, the great abundance of land snail shells (e.g., Yanes et al., 2004), frequent brood cells of solitary bees (Ellis and Ellis-Adam, 1993; Edwards and Meco, 2000; Alonso-Zarza and Silva, 2002), and nests of coleopterans (Genise and Edwards, 2003) merit special attention.

A total of 14 stratigraphic sections that included 44 individual dune and paleosol levels have been studied and sampled (Fig. 1; Table 1). Each section is named using a three-letter acronym combining the name of island-islet on which that section is located and the name of site where the section was sampled. For example, Barranco de los Encantados section from Fuerteventura Island is named FBE. Additional details about each island and stratigraphic section figures are provided in Ortiz et al. (2006).

\subsection{Materials and methods}

We have focused primarily on shells of the helicid gastropod Theba geminata (Mousson) (Fig. 2A). However, in one locality (MCG-1), analyzed specimens also included the second congeneric species Theba arinagae Gittenberger and Ripken (Fig. 2B). The genus Theba was selected because it is the most abundant taxon on the eastern Canary Islands (Gittenberger and Ripken, 1987; Gittenberger et al., 1992), whereas both species sampled here occur throughout the entire fossil record of the

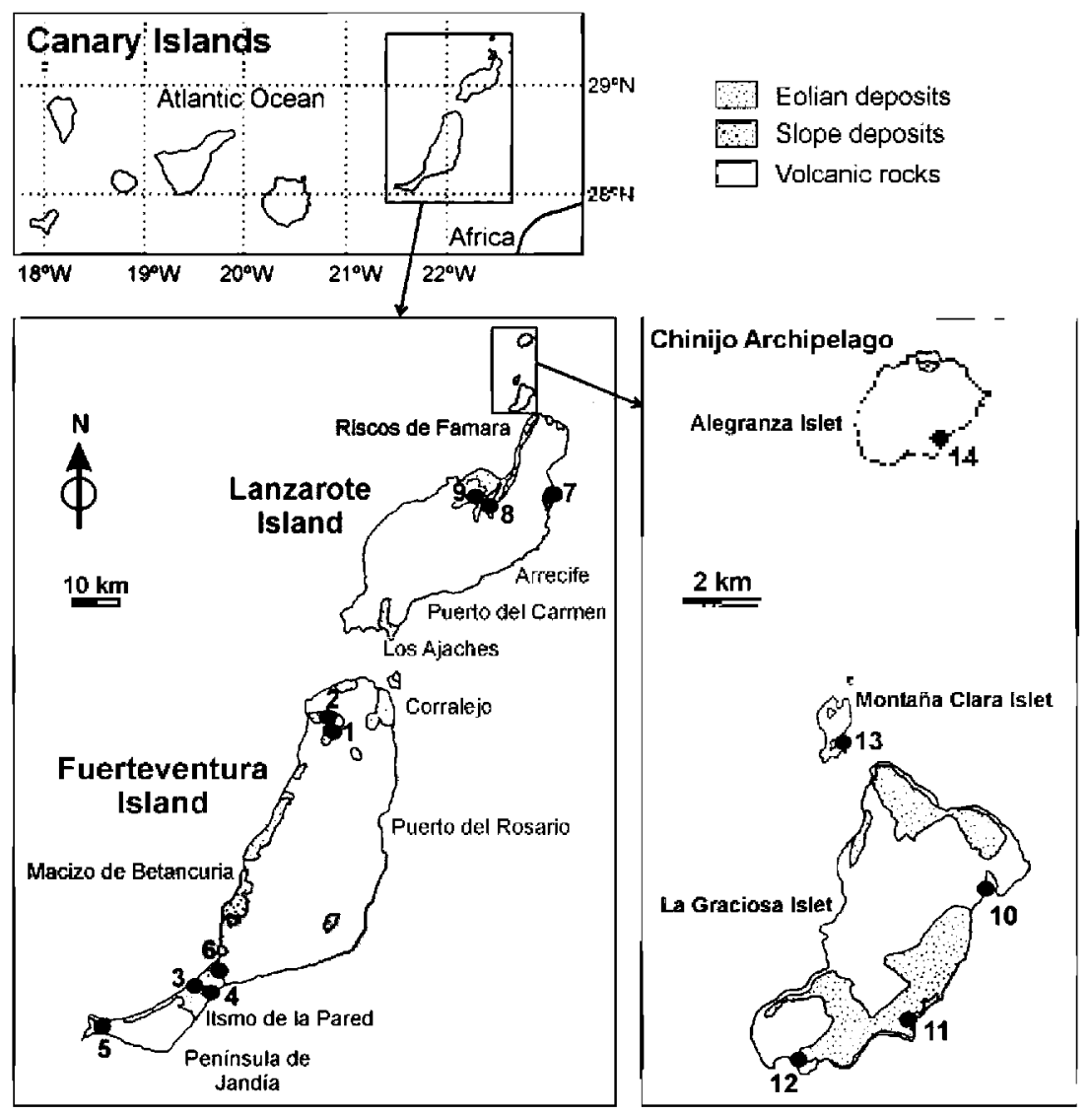

Fig. 1. Geographical location of Fuerteventura and Lanzarote Islands and La Graciosa, Montaña Clara and Alegranza Islets. The sampled sections are as follows: (1) Barranco de los Encantados (FBE), (2) Montaña de la Costilla (FMC), (3) Barranco del Pecenescal (FBP), (4) Atalayeja Grande (FAG), (5) Montan̄a Azufrá (FMA), (6) Hueso del Caballo (FHC), (7) Mala (LMA), (8) Loma de San Andrés (LLA), (9) Tao (LTA), (10) Morros Negros (GMN), (11) Caleta del Sebo (GCS), (12) La Cocina (GLC), (13) Caleta de Guzmán (MCG), (14) Montaña Lobos (AML). Modified after Ortiz et al. (2006). 
Table 1

Summary of the studied sections

\begin{tabular}{|c|c|c|c|c|c|c|c|c|}
\hline Island & Section name & Section ID & Longitude & Latitude & $\begin{array}{l}\text { Elevation } \\
(\mathrm{m})\end{array}$ & $\begin{array}{l}\text { Thickness } \\
\text { (m) }\end{array}$ & $\begin{array}{l}\text { Number of } \\
\text { studied horizons }\end{array}$ & $n$ \\
\hline \multirow[t]{6}{*}{ Fuerteventura $(\mathrm{F})$} & Barranco de los Encantados & FBE & $28^{\circ} 38^{\prime} 12^{\prime \prime} \mathrm{N}$ & $13^{\circ} 59^{\prime} 4^{\prime \prime} W$ & 153 & 15.7 & 7 & 32 \\
\hline & Montana de la Costilla & FMC & $28^{\circ} 41^{\prime} 16^{\prime \prime} \mathrm{N}$ & $13^{\circ} 58^{\prime} 9^{\prime \prime} \mathrm{W}$ & 55 & 14.5 & 3 & 15 \\
\hline & Barranco del Pecenescal & FBP & $28^{\circ} 7^{\prime} 42^{\prime \prime} \mathrm{N}$ & $14^{\circ} 16^{\prime} 49^{\prime \prime} \mathrm{W}$ & 95 & 7.8 & 1 & 5 \\
\hline & Atalayeja Grande & FAG & $28^{\circ} 8^{\prime} 53^{\prime \prime} \mathrm{N}$ & $14^{\circ} 17^{\prime} 18^{\prime \prime} \mathrm{W}$ & 237 & 14.9 & 3 & \\
\hline & Montaña Azufrá & FMA & $28^{\circ} 5^{\prime} 41^{\prime \prime} \mathrm{N}$ & $14^{\circ} 27^{\prime} 52^{\prime \prime} \mathrm{W}$ & 90 & 6.0 & 1 & \\
\hline & Hueso del Caballo & FHC & $28^{\circ} 10^{\prime} 17^{\prime \prime} \mathrm{N}$ & $14^{\circ} 14^{\prime} 33^{\prime \prime} \mathrm{W}$ & 100 & 5.0 & 2 & \\
\hline \multirow[t]{3}{*}{ Lanzarote (L) } & Loma de San Andrés & LLA & $29^{\circ} 2^{\prime} 12^{\prime \prime} \mathrm{N}$ & $13^{\circ} 36^{\prime} 48^{\prime \prime} \mathrm{W}$ & 280 & 9.0 & 2 & \\
\hline & Tao & LTA & $29^{\circ} 2^{\prime} 36^{\prime \prime} \mathrm{N}$ & $13^{\circ} 36^{\prime} 51^{\prime \prime} \mathrm{W}$ & 247 & 4.3 & 2 & \\
\hline & Mala & LMA & $29^{\circ} 5^{\prime} 43^{\prime \prime} \mathrm{N}$ & $13^{\circ} 27^{\prime} 38^{\prime \prime} \mathrm{W}$ & 25 & 15.0 & 7 & 36 \\
\hline \multirow[t]{3}{*}{ La Graciosa (G) } & Morros Negros & GMN & $29^{\circ} 15^{\prime} 22^{\prime \prime} \mathrm{N}$ & $13^{\circ} 29^{\prime} 16^{\prime \prime} \mathrm{W}$ & 10 & 12.5 & 8 & 43 \\
\hline & Caleta del Sebo & GCS & $29^{\circ} 13^{\prime} 38^{\prime \prime} \mathrm{N}$ & $13^{\circ} 30^{\prime} 12^{\prime \prime} \mathrm{W}$ & 2 & 4.5 & 2 & 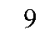 \\
\hline & La Cocina & GLC & $29^{\circ} 13^{\prime} 8^{\prime \prime} \mathrm{N}$ & $13^{\circ} 32^{\prime} 6^{\prime \prime} W$ & 25 & 18.0 & 2 & \\
\hline Montafia Clara (M) & Caleta de Guzmán & $\mathrm{MCG}$ & $29^{\circ} 16^{\prime} 35^{\prime \prime} \mathrm{N}$ & $13^{\circ} 31^{\prime} 46^{\prime \prime} \mathrm{W}$ & 3 & 8.0 & 3 & 14 \\
\hline Alegranza (A) & Montaña Lobos & AML & $29^{\circ} 23^{\prime} 20^{\prime \prime} \mathrm{N}$ & $13^{\circ} 30^{\prime} 10^{\prime \prime} \mathrm{W}$ & 30 & 0.4 & 1 & 5 \\
\hline
\end{tabular}

Abbreviations: $n-$ number of shells analyzed per each section.

genus (Castillo et al., 2002; Yanes et al., 2004). Both species possess calcium carbonate (aragonite) shells that can be dated to evaluate the scale of time-averaging (i.e., within-horizon age mixing among individual fossils) in the eolian deposits in the study area. It should be noted also that no shell-bearing species other than Theba are both abundant and continuously present throughout the late Quaternary record of the eastern Canary Islands (Yanes et al., 2004).

Sampled shells of Theba are globose-spherical in shape and average $15 \mathrm{~mm}$ in width and $11 \mathrm{~mm}$ in height. Although the two studied species are endemic to the eastern islands of the Canary Archipelago, the genus is widely represented by the species Theba pisana (Müller) that is known from Quaternary eolian deposits of the Mediterranean area, the Western Europe, and the northern Africa (Kerney and Cameron, 1979). The studied gastropod species displays an epifaunal mode of life. Based on the cogeneric species Theba pisana (e.g., Cowie, 1984), its most likely reproductive cycle is annual to bi-annual. The studied Theba species are mostly active at night and/or during wet weather (M. Ibáñez, personal communication, 2006). When inactive, they usually aggregate on shrubs and bushes, which also represent their primary food source (direct field observations, 2004).

The shell samples were collected during 2002-2004 field seasons by the La Laguna University paleontology group. Shells collected for amino acid epimerization dating were sampled from trenches at least $30-$ to $-50 \mathrm{~cm}$ below the land/outcrop surface to avoid surface contamination and minimize the effect of surficial heating. The sampling depth of $30-$ to $-50 \mathrm{~cm}$ is guided by a pre- vious study of racemization rates in mollusk shells along a depth profile in a setting similar to that of our study area: a subaerially exposed, subtropical coastal setting on supratidal flats of the Colorado River Delta, Mexico. This previous analysis demonstrated that surficial heating affects noticeably only those shells that are buried within the topmost $20 \mathrm{~cm}$ of sediment (Goodfriend et al., 1995; Kowalewski et al., 1998). Because of possible thermal variation among even similar settings, we have conservatively excluded shells down to at least $30 \mathrm{~cm}$. The additional reason for excluding surficial and shallowly buried shells is to prevent contamination by foreign amino acids introduced by recent biological activity (Torres et al., 2000).

A total of 203 Helicidae samples were sampled, including specimens of Theba geminata (all localities, $n=197$ specimens) and Theba arinagae (level MCG-1 only, $n=6$ specimens) from 14 stratigraphic sections (Table 1): 8 levels belong to GMN, 2 to GCS, 2 to GLC, 3 to $\mathrm{MCG}, 1$ to AML, 2 to LLA, 2 to LTA, 7 to LMA, 7 to FBE, 3 to FMC, 1 to FBP, 3 to FAG, 2 to FHC, and 1 to FMA (see the stratigraphy of the sections in Ortiz et al., 2006).

\subsection{Amino acid racemization/epimerization dating}

Although multiple amino acids can be recognized and employed in order to determinate the age of the deposits (e.g., Goodfriend, 1991; Torres et al., 1997; Csapò et al., 1998; Ortiz et al., 2004; Ortiz et al., 2006), we focused here on the ratio of $\mathrm{D}$-alloisoleucine (A) to $\mathrm{L}$ isoleucine (I) to date the shells. This is because the use of a single amino acid simplifies the numerical analysis of 


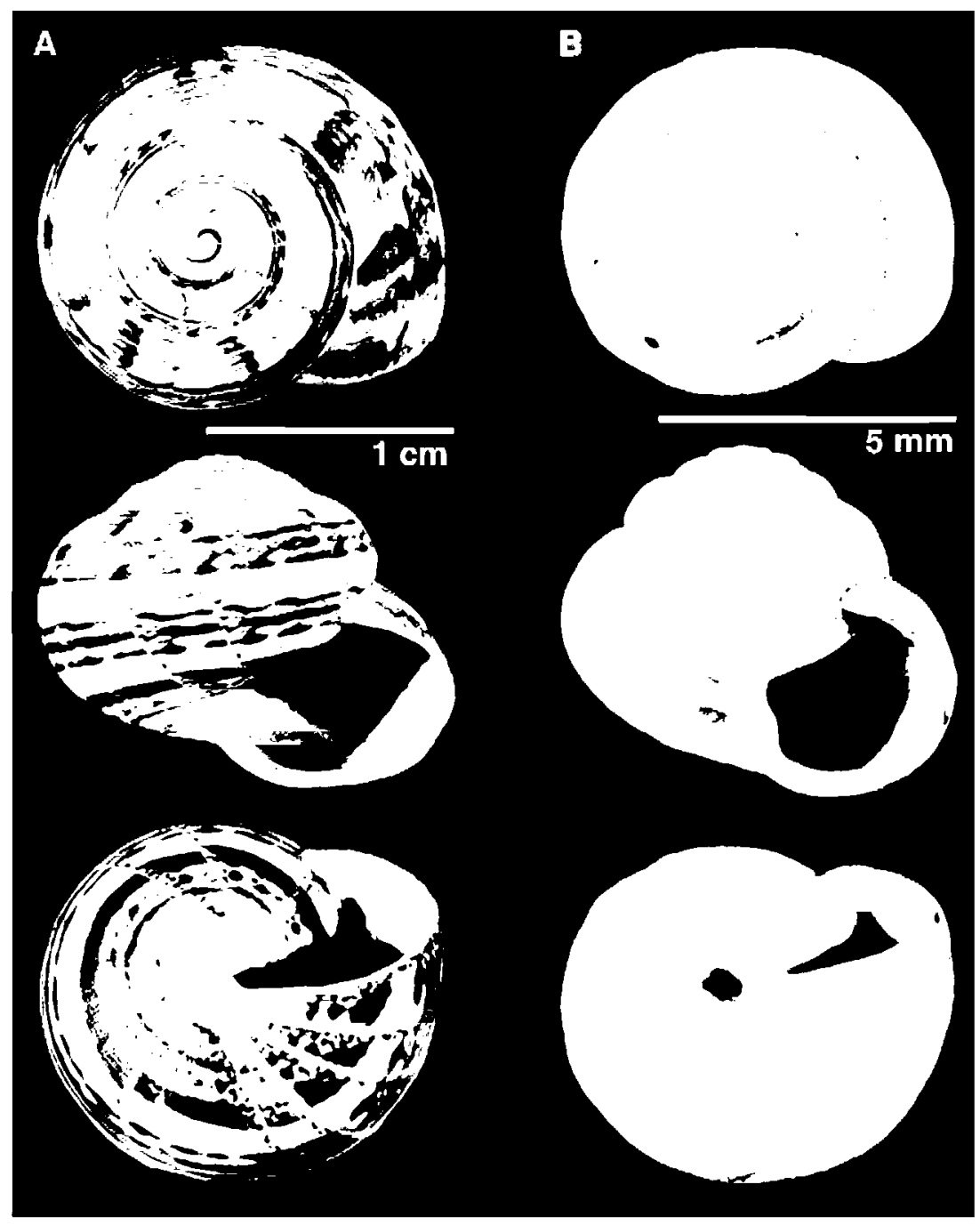

Fig. 2. Examples of the endemic helicid gastropods Theba geminata (A) and Theba arinagae (B) dated in this study using the combination of aminoacid racemization rates calibrated against radiocarbon (photographs courtesy of Miguel Ibáñez, La Laguna University, 2005).

time-averaging within shell beds. Indeed, all previous studies estimating age-mixing have targeted only one amino acid (e.g., Kowalewski et al., 1998; Carroll et al., 2003; Kidwell et al., 2005). Additionally, the isoleucine has been commonly used in previous studies that aimed to evaluate age mixing within the late Quaternary shell assemblages (e.g., Goodfriend, 1989; Martin et al., 1996; Kowalewski et a1., 1998; Carroll et al., 2003; but see Kidwell et al., 2005; Barbour Wood et al., 2006).

All shells were field collected by hand using latex gloves and tweezers to avoid possible contamination with modern amino acids. The initial taxonomic identification and specimen selection were carried out in the field. Each of the sampled specimens was assigned a unique label and placed separately in a sealed plastic bag. Shells were carefully sonicated and cleaned with water to remove the sediment contained inside the shells. Subsequently, each specimen was treated briefly (a few seconds) with $2 \mathrm{~N} \mathrm{HCl}$ - a brief application of an aggressive solvent has been recommended in multiple studies to eliminate any possible microbialfungi carbonate crusts containing recent amino acids (e.g., Brooke et al., 2003a; Hearty, 2003). Following the acid treatment, an aliquot $(70-80 \mathrm{mg}$ ) of shell was acquired using tweezers and weighted using an analytical balance with a microdraft shield. All aliquots were acquired from the same shell region and shell layer to minimize the effects of intra-shell variability in 
racemization/epimerization rates, documented previously for multiple shelly taxa (e.g., Goodfriend et al., 1997; Carroll et al., 2003).

The sample preparation protocol follows a standard procedure described in Goodfriend (1991) and Goodfriend and Meyer (1991) and summarized in Ortiz et al. (2006). It included the following steps: (1) hydrolysis under $\mathrm{N}_{2}$ atmosphere in a mixture of $12 \mathrm{~N} \mathrm{HCl}$ $(2.9 \mu \mathrm{l} / \mathrm{mg})$ and $6 \mathrm{~N}$ hydrochloric acid $(100 \mu \mathrm{l})$ for $20 \mathrm{~h}$ at $100^{\circ} \mathrm{C}$; desalting with $\mathrm{HF}$, freezing and drying of the supernatant under vacuum; and (2) derivatization, first involving esterification with $250 \mu 1$ of $3 \mathrm{M}$ thionyl chloride in isopropanol for $1 \mathrm{~h}$ at $100^{\circ} \mathrm{C}$ under $\mathrm{N}_{2}$; and second, drying samples and acylatizing with $200 \mu \mathrm{l}$ of trifluoroacetic acid anhydride $(25 \%$ in dichloromethane) for $5 \mathrm{~min}$ at $100{ }^{\circ} \mathrm{C}$. Excesses of derivative and solvent were evaporated under a gentle flow of nitrogen. The sample was taken up in $100 \mu 1$ of $n$-hexane.

The samples were measured in Biomolecular Stratigraphy Laboratory, Universidad Politécnica de MadridSpain. Aliquots (1-4 $\mu 1)$ were injected into a HewlettPackard 5890 gas chromatograph. The injection port was kept at $215^{\circ} \mathrm{C}$ and set for "splitless mode" when the sample was injected. After the first $75 \mathrm{~s}$, the port was set to "split mode". Helium was used as the carrier gas, at a column head pressure of $5.8 \mathrm{psi}$, with a Chirasil-L-Val fused silica column $(0.39 \mathrm{~mm} \times 0.25 \mu \mathrm{m} \times 25 \mathrm{~m})$ from Chrompack. The detector used was an NPD set at $300^{\circ} \mathrm{C}$ (see Ortiz et al., 2006 for more details).

Because all analyzed specimens belong to closely related species ( $T$. geminata and $T$. arinagae) from a single genus, a taxonomically driven variability in $\mathrm{D} / \mathrm{L}$ amino acid ratios is unlikely to be a major factor (see also Murray-Wallace, 1995).

Prior to the main analytical phase of the study (described below), shells were evaluated for diagenetic alteration. We analyzed 94 shells belonging to 12 different land snail species through X-ray diffraction in order to evaluate preservation grade of the fossils. The analyzed material was collected randomly from five islands (Fuerteventura, Lanzarote, La Graciosa, Montaña Clara and Alegranza), eight sections (AML, MCG, GMN, GCS, GLC, LMA, FBE, FAG, and FBP) and 33 levels of dunes and paleosols as well (Table 2). X-ray diffraction analyses were performed in the Instituto Universitario de Bio-orgánica Antonio González (IUBIO-AG) of the La Laguna University-Spain, using PANalytical X'Pert for poly-crystalline samples. The results suggest that all the studied shells preserve their original aragonite composition with an average probability of $95 \%$ (Table 2). These findings suggest that notable diagenetic alterations are unlikely to have affected the studied material. Nevertheless, it should be noted here that the amino acid dating of numerous specimens carried out in this study increases a chance of an inclusion of few diagenetically altered specimens with anomalous ages. Specifically for this study - and assuming the worst case scenario possible that any diagenetic alteration always induces a significant dating bias - about 10 shells ( $\sim 5 \%$ of 203 shells dated here) may be expected to yield anomalous ages due to diagenesis alone. Consequently, age anomalies displayed by a small fraction of specimens $(\sim 5 \%)$ can be explained as a spurious preservational effect and does not demonstrate conclusively that time-averaging affects the studied shell assemblages.

Given the strict taxonomic and sampling constraints outlined above and lack of extensive evidence for diagenetic overprint, we assume that the error in individual estimates of amino acid ratios is primarily driven by laboratory analytical error, which is estimated for our data at around 3\% (Murray-Wallace, 1995).

\subsection{Radiocarbon calibration}

Nine Theba geminata specimens were analyzed by radiocarbon dating in Gliwice Radiocarbon Laboratory of the Silesian University of Technology-Poland. Three specimens (GMN-3, GCS-1 and MCG-1) were dated by De La Nuez et al. (1997) using the conventional radiometric technique. Six specimens (MGC-3, FMC-1, FMC-3, FAG-3, LMA-2, and one shell from a live-collected land snail) were analyzed by Ortiz et al. (2006) using AMS radiocarbon dating (Table 3 ). The protocol procedure and the correction and calibration of the radiocarbon data is summarized by Ortiz et al. (2006).

Multiple approaches (models), which integrate radiocarbon and amino-acid racemization rates, can be used to convert amino-acid ratios into numerical age estimates expressed in years. Traditionally, two main types of models have been used by geochronologists: (1) the first-order kinetics (FOK), which relates the expression $\operatorname{Ln}[(1+\mathrm{D} / \mathrm{L}) /(1-\mathrm{D} / \mathrm{L})]$ to the time or square root of time; and (2) the apparent parabolic kinetics (APK), which relates directly the $\mathrm{D} / \mathrm{L}$ ratio to the time or square root of time. Because neither of the models appears to apply universally to all amino acid systems, for any given dataset, a specific approach must be selected empirically based on the model performance (the goodness of fit) (Goodfriend, 1991). In the case of dated shells used here, Ortiz et al. (2006) selected the best algorithm by comparing correlation coefficients 
Table 2

Semi-quantitative estimates (SQ) of mineralogical composition of land snail shells from late Quaternary dune and paleosol horizons

\begin{tabular}{|c|c|c|c|c|c|}
\hline Sample ID & Sediment level type & Age (kyr BP) & Species & Aragonite (SQ \%) & Calcite (SQ \%) \\
\hline FBP-1B-1 & Paleosol & $15.2 \pm 3.4$ & Monilearia monilifera & 66 & 34 \\
\hline FBP-1B-2 & Paleosol & $15.2 \pm 3.4$ & Caracollina lenticula & 98 & 2 \\
\hline FAG-3B-1 & Paleosol & $5.4 \pm 1.7$ & Theba arinagae & 98 & 2 \\
\hline FBE-1B-1 & Paleosol & $48.1 \pm 5.6$ & Theba geminata & 96 & 4 \\
\hline FBE-2A-1 & Dune & $47.8 \pm 5.7$ & Theba geminata & 97 & 3 \\
\hline FBE-2B-1 & Paleosol & $47.8 \pm 5.7$ & Theba geminata & 100 & 0 \\
\hline FBE-3B-1 & Paleosol & $46.6 \pm 6.5$ & Theba arinagae & 96 & 4 \\
\hline FBE-4B-1 & Paleosol & $38.9 \pm 6.4$ & Theba geminata & 100 & 0 \\
\hline FBE-5B-1 & Paleosol & $37.6 \pm 4.9$ & Canariella plutonia & 100 & 0 \\
\hline FBE-5B-2 & Paleosol & $37.6 \pm 4.9$ & Hemicycla paeteliana & 98 & 2 \\
\hline FBE-5B-3 & Paleosol & $37.6 \pm 4.9$ & Pomatias lanzarotensis & 98 & 2 \\
\hline FBE-5B-4 & Paleosol & $37.6 \pm 4.9$ & Theba geminata & 100 & 0 \\
\hline FBE-6B-1 & Paleosol & $37.5 \pm 4.2$ & Theba geminata & 99 & 1 \\
\hline LMA-1A-1 & Dune & $38.6 \pm 6.9$ & Theba arinagae & 100 & 0 \\
\hline LMA-1B-1 & Paleosol & $38.6 \pm 6.9$ & Theba geminata & 100 & 0 \\
\hline LMA-2B-1 & Paleosol & $39.8 \pm 4.6$ & Theba arinagae & 67 & 33 \\
\hline LMA-2B-2 & Paleosol & $39.8 \pm 4.6$ & Theba geminata & 100 & 0 \\
\hline LMA-3B-1 & Paleosol & $34.9 \pm 5.3$ & Theba geminata & 100 & 0 \\
\hline LMA-4B-1 & Paleosol & $30.6 \pm 4.2$ & Theba geminata & 100 & 0 \\
\hline LMA-5A-1 & Dune & $31.1 \pm 3.2$ & Theba geminata & 94 & 6 \\
\hline LMA-5B-1 & Paleosol & $31.1 \pm 3.2$ & Canariella plutonia & 100 & 0 \\
\hline LMA-5B-2 & Paleosol & $31.1 \pm 3.2$ & Pomatias lanzarotensis & 96 & 4 \\
\hline LMA-5B-3 & Paleosol & $31.1 \pm 3.2$ & Theba impugnata & 96 & 4 \\
\hline LMA-6B-1 & Paleosol & $27.4 \pm 4.4$ & Monilearia monilifera & 100 & 0 \\
\hline LMA-6B-2 & Paleosol & $27.4 \pm 4.4$ & Rumina decollata & 88 & 12 \\
\hline LMA-6B-3 & Paleosol & $27.4 \pm 4.4$ & Theba arinagae & 92 & 8 \\
\hline LMA-7B-1 & Paleosol & $28.2 \pm 5.1$ & Monilearia monilifera & 97 & 3 \\
\hline LMA-7B-2 & Paleosol & $28.2 \pm 5.1$ & Rumina decollata & 94 & 6 \\
\hline LMA-7B-3 & Paleosol & $28.2 \pm 5.1$ & Theba arinagae & 91 & 9 \\
\hline GLC-1B-1 & Paleosol & $31.5 \pm 5.7$ & Theba arinagae & 96 & 4 \\
\hline GLC-1B-2 & Paleosol & $31.5 \pm 5.7$ & Pomatias lanzarotensis & 100 & 0 \\
\hline GLC-1B-3 & Paleosol & $31.5 \pm 5.7$ & Theba geminata & 97 & 3 \\
\hline GLC-1B-4 & Paleosol & $31.5 \pm 5.7$ & Monilearia monilifera & 96 & 4 \\
\hline GLC-1B-5 & Paleosol & $31.5 \pm 5.7$ & Rumina decollata & 94 & 6 \\
\hline GLC-1B-6 & Paleosol & $31.5 \pm 5.7$ & Theba arinagae & 88 & 12 \\
\hline GLC-1B-7 & Paleosol & $31.5 \pm 5.7$ & Monilearia monilifera & 95 & 5 \\
\hline GLC-1B-8 & Paleosol & $31.5 \pm 5.7$ & Theba geminata & 68 & 32 \\
\hline GLC-2B-1 & Paleosol & $24.8 \pm 4.4$ & Theba geminata & 97 & 3 \\
\hline GLC-2B-2 & Paleosol & $24.8 \pm 4.4$ & Monilearia monilifera & 98 & 2 \\
\hline GLC-2B-3 & Paleosol & $24.8 \pm 4.4$ & Theba arinagae & 97 & 3 \\
\hline GLC-2B-4 & Paleosol & $24.8 \pm 4.4$ & Theba arinagae & 92 & 8 \\
\hline GCS-1B-1 & Paleosol & $30.3 \pm 5.5$ & Theba arinagae & 100 & 0 \\
\hline GCS-1B-2 & Paleosol & $30.3 \pm 5.5$ & Theba geminata & 91 & 9 \\
\hline GCS-2B-1 & Paleosol & $20.6 \pm 3.4$ & Theba arinagae & 92 & 8 \\
\hline GCS-2B-2 & Paleosol & $20.6 \pm 3.4$ & Hemicycla sarcostoma & 98 & 2 \\
\hline GCS-2B-3 & Paleosol & $20.6 \pm 3.4$ & Theba geminata & 92 & 8 \\
\hline
\end{tabular}

Ages based on radiocarbon-calibrated amino acid racemization/epimerization dates of individual shells (see Ortiz et al., 2006). The species used in the geochronological analysis are restricted to $T$. geminata and T. arinagae only $(n=28)$.

between time and $\mathrm{D} / \mathrm{L}$ ratio. Those comparisons suggested that, for the isoleucine (the amino acid used here) from shells collected around the Canary Islands, the best model for deriving the numerical age is achieved by estimating the direct relationship between $\mathrm{D} / \mathrm{L}$ ratio and time. For other amino acids, other approaches were suggested based on the correlation coefficients. The amino-chronological algorithm with the highest correlation coefficient was as follows:

$t=-1.939+60.42 \mathrm{D}-$ alle $/ \mathrm{L}-\mathrm{Ile}$,

where $t$ is age in calendar years BP (Fig. 3). This equation was applied to estimate the calendar age of each 
Table 3

$\mathrm{D} / \mathrm{L}$ isoleucine ratio and radiocarbon dates obtained from shells of fossil land snail from the Quaternary deposits of the Canary Islands

\begin{tabular}{llr} 
Sample ID & A/I-value & Calibrated ${ }^{14} \mathrm{C}$ age $(\mathrm{yr} \mathrm{BP})$ \\
Modern shell & 0.001 & 0 \\
MCG-3 & 0.113 & 3250 \\
FMC-3 & 0.156 & 3810 \\
FAG-3 & 0.163 & 4750 \\
GCS-1 & 0.452 & 36,160 \\
MCG-1 & 0.698 & 38,890 \\
GMN-3 & 0.734 & 39,820 \\
FMC-1 & 0.813 & 42,530 \\
LMA-1 & 0.684 & 43,810 \\
\hline
\end{tabular}

The listed specimens were used to calibrate the amino-acid racemization rates and to estimate standard errors of calibrations used in simulations presented in this study. The ${ }^{14} \mathrm{C}$ ages of the samples were corrected for an age anomaly of $2724 \pm 32$ yr obtained in live-collected Theba shells from the Canary Islands (Ortiz et al., 2006). This age anomaly is induced by ingestion of foreign (older) carbonates by land snails, which utilize ingested carbonates to secrete their shells.

Theba specimen that was individually dated using $\mathrm{D} / \mathrm{L}$ ratios. However, it is noteworthy here that the choice of the specific amino acid used for estimates shell ages, or even the choice of the model and equation used in radiocarbon calibration, do not matter from the practical standpoint. Regardless of the amino-acid system and calibration algorithm, the key results presented here (which center primarily on dispersion in age estimates, and not the absolute value of the estimates) do not change significantly. The preliminary analyses for other amino acids and other calibration models (not shown here) all yielded time-averaging estimates comparable to those reported below.

\subsection{Artificial time-averaging due to dating imprecision}

Time-averaging (age mixing) among individuals needs to be evaluated relative to the expected variation in shell age due to dating imprecisions alone. Such artificial time-averaging can be estimated empirically by evaluating the quality of the radiocarbon calibration of amino acid ratios (e.g., Goodfriend, 1989; Kowalewski et a1., 1998; Carroll et al., 2003). Namely, the standard error of the calibration (which can be expressed in years) is an empirical estimate of combined imprecisions in $\mathrm{D} / \mathrm{L}$ ratios induced by analytical errors $(\sim 3 \%)$, the intra-shell $(\sim 8 \%)$ and inter-shell $(\sim 12 \%)$ variabilities in $\mathrm{D} / \mathrm{L}$ ratios, and the unknown variation induced by differences in thermal history (unlikely to be large within individual horizons) (Murray-Wallace, 1995). This standard error is expected to increase with shell age because $\mathrm{D} / \mathrm{L}$ ratio errors tend to behave in a percentwise fashion (Wehmiller and Miller, 2000). Consequently, for shell ages span- ning over tens of thousands of years it is appropriate to estimate imprecision for different age groups separately. In the case of the calibrations used here, Ortiz et al. (2006) noted that, as expected, young ${ }^{14} \mathrm{C}$-dated shells $(<20,000$ years BP) had a much tighter calibration than the old shells $\left(>20,000\right.$ years BP). Using their ${ }^{14} \mathrm{C}$ calibrations, we have estimated standard errors at 400 years for the young shells and 2370 years for the old shells. These estimated standard errors were derived using two separate regression analyses, one for older shells and other for younger shells. This division reflects a significant temporal gap in a time series of the available radiocarbon dates between $\sim 5000$ and $\sim 36,000$ years BP (Ortiz et al., 2006). The radiocarbon ages and amino acid ratios used in those two regression analyses are provided in Table 3. For each of the two regression models, standard errors were computed using a simple linear regression model (PROC REG procedure, SAS/ STAT software). Other regression models, including a major-axis regression (PAST freeware; Hammer et al., 2001), which assumes errors for both the dependent variable and the independent variable (Fig. 3), yielded comparable estimates of standard errors.

Using these estimates we can define the scale of artificial age mixing that would be expected for samples that were collected from shell horizons that were not affected by any temporal mixing. Namely, if all shells were of exactly the same age (e.g., no time-averaging), the sample of dated shells should, on average, have a standard deviation that approximates the standard error of the calibration. These estimates of the expected apparent time-averaging due to the dating error can then be compared to the observed values.

In addition, to provide a probabilistic assessment of the observed time-averaging, we employ here a simple Monte Carlo model, where samples are simulated iteratively using the above standard errors. For example, for

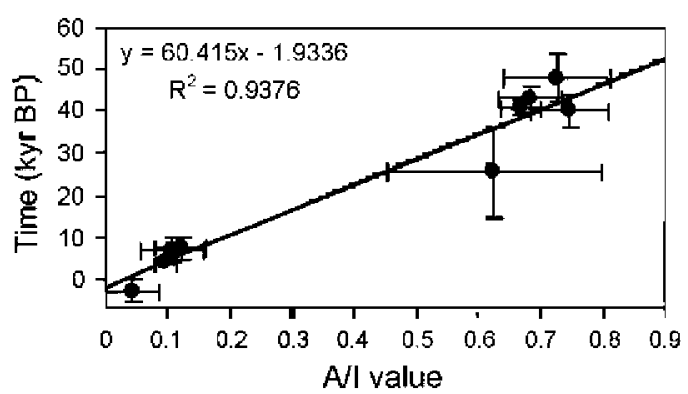

Fig. 3. Apparent parabolic kinetics of the untransformed $D / L$ ratio of isoleucine (A/I value) versus time analyzed for helicid shells collected from the Canary Archipelago. Adapted after Ortiz et al. (2006) Whiskers represent the residuals of both plotted variables. 
a sample of 5 dated shells with a mean age of 7500 years BP (sample FMC-3 in Table 4), a sample of 5 random values is drawn from a normal distribution with a mean of 7500 years and the standard deviation of 400 years. The assumption of normal distributed errors is reasonable given that dating errors are expected to be so distributed. Moreover, when multiple sources of errors are averaged out, the distribution of combined errors is expected to converge on normality, as predicted by the
Central Limit Theorem. For the resulting random sample, which simulates artificial time-averaging due to dating imprecisions, a series of parameters including standard deviation, interquartile range, skewness, and kurtosis are recorded. The simulation is repeated 10,000 times to build empirical probability density function estimating the distribution of standard deviation values (and other parameters) when the null model (artificial time-averaging only) is expected. The actual values of

Table 4

Summary of descriptive statistics of age distributions of dated shells analyzed separately for each sampled stratigraphic horizon

\begin{tabular}{|c|c|c|c|c|c|c|c|c|c|c|}
\hline Sample (horizon) & $n$ & Range (yr) & $\mathrm{SD}(\mathrm{yr})$ & IQ (yr) & Mean (yr) & Median (yr) & $\mathrm{MIN}(\mathrm{yr})$ & $\operatorname{MAX}(\mathrm{yr})$ & $S$ & $K$ \\
\hline GMN-1 & 5 & 5940 & 2560 & 3790 & 41,540 & 42,590 & 38,280 & 44,220 & -0.49 & -2.35 \\
\hline GMN-2 & 6 & 6730 & 2350 & 2300 & 41,870 & 41,900 & 38,480 & 45,210 & -0.04 & -0.25 \\
\hline GMN-3 & 6 & 10,730 & 4300 & 6990 & 42,400 & 40,550 & 37,670 & 48,400 & 0.72 & -1.47 \\
\hline GMN-4 & 5 & 4470 & 1640 & 760 & 39,090 & 38,620 & 37,200 & 41,680 & 0.98 & 1.89 \\
\hline GMN-5 & 6 & 7080 & 2570 & 2420 & 46,460 & 45,850 & 44,080 & 51,160 & 1.47 & 2.32 \\
\hline GMN-6 & 5 & 9740 & 4050 & 1860 & 29,380 & 30,670 & 22,290 & 32,030 & -2.00 & 4.15 \\
\hline GMN-7 & 5 & 4590 & 1930 & 2750 & 13,810 & 14,490 & 11,480 & 16,070 & -0.25 & -2.19 \\
\hline GMN-8 & 5 & 13,210 & 5170 & 5210 & 16,460 & 16,220 & 11,150 & 24,360 & 0.88 & 0.55 \\
\hline GCS-1 & 3 & 1960 & 1050 & 1960 & 25,400 & 25,830 & 24,200 & 26,160 & -1.54 & $\mathrm{n} / \mathrm{a}$ \\
\hline GCS-2 & 6 & 8390 & 2740 & 950 & 19,810 & 19,380 & 16,380 & 24,770 & 1.18 & 3.00 \\
\hline GLC-1 & 5 & 5160 & 2210 & 3480 & 30,500 & 30,870 & 27,930 & 33,090 & -0.12 & -2.35 \\
\hline GLC-2 & 4 & 5710 & 2440 & 3500 & 25,660 & 25,240 & 23,210 & 28,930 & 0.88 & 0.76 \\
\hline MCG-1 & 4 & 11,970 & 5080 & 7410 & 40,240 & 39,600 & 34,900 & 46,870 & 0.66 & 0.36 \\
\hline MCG-2 & 5 & 7210 & 3670 & 6204 & 26,650 & 29,230 & 22,190 & 29,410 & -0.64 & -3.12 \\
\hline MCG-3 & 5 & 9090 & 3950 & 480 & 4900 & 3320 & 2860 & 11,950 & 2.22 & 4.93 \\
\hline AML-1 & 5 & 3610 & 1410 & 770 & 5020 & 4700 & 3780 & 7400 & 1.65 & 3.09 \\
\hline FBE-1 & 5 & 15,300 & 6800 & 10,920 & 49,720 & 52,310 & 41,500 & 56,800 & -0.42 & -2.69 \\
\hline FBE-2 & 5 & 9070 & 3400 & 900 & 51,730 & 50,760 & 48,360 & 57,430 & 1.54 & 3.17 \\
\hline FBE-3 & 3 & 6820 & 3410 & 6820 & 48,780 & 48,620 & 45,450 & 52,270 & 0.21 & $\mathrm{n} / \mathrm{a}$ \\
\hline FBE-4 & 5 & 6070 & 2520 & 1050 & 42,100 & 41,100 & 40,440 & 46,520 & 2.03 & 4.23 \\
\hline FBE-5 & 5 & 3150 & 1190 & 730 & 37,860 & 38,120 & 35,920 & 39,070 & -1.33 & 2.27 \\
\hline FBE-6 & 5 & 3640 & 1560 & 2020 & 37,830 & 38,670 & 35,570 & 39,200 & -0.91 & -1.17 \\
\hline FBE-7 & 4 & 1140 & 510 & 800 & 35,670 & 35,600 & 35,160 & 36,300 & 0.54 & -1.62 \\
\hline FBP-1 & 5 & 5220 & 1980 & 1280 & 15,750 & 15,470 & 13,760 & 18,980 & 1.30 & 2.16 \\
\hline FMA-1 & 3 & 9610 & 4970 & 9610 & 34,470 & 35,910 & 28,950 & 38,560 & -1.20 & $\mathrm{n} / \mathrm{a}$ \\
\hline FMC-1 & 5 & 2460 & 1050 & 1620 & 47,200 & 47,360 & 45,980 & 48,440 & -0.10 & -2.27 \\
\hline FMC-2 & 5 & 6540 & 2730 & 4000 & 44,070 & 44,640 & 40,530 & 47,070 & -0.36 & -1.94 \\
\hline FMC-3 & 5 & 6160 & 2650 & 3740 & 7500 & 6690 & 5180 & 11,330 & 0.81 & -0.97 \\
\hline FAG-1 & 3 & 9770 & 5010 & 9770 & 48,220 & 46,970 & 43,960 & 53,730 & 1.05 & $\mathrm{n} / \mathrm{a}$ \\
\hline FAG-2 & 4 & 2490 & 1150 & 1320 & 21,520 & 21,070 & 20,740 & 23,230 & 1.87 & 3.61 \\
\hline FAG-3 & 2 & 10,180 & 7200 & 10,180 & 7900 & 7900 & 2810 & 12,990 & $\mathrm{n} / \mathrm{a}$ & $\mathrm{n} / \mathrm{a}$ \\
\hline FHC-1 & 4 & 11,470 & 5310 & 8090 & 30,510 & 29,110 & 26,180 & 37,650 & 1.02 & -0.34 \\
\hline FHC-2 & 4 & 3750 & 1580 & 2350 & 24,080 & 24,120 & 22,170 & 25,920 & -0.14 & -0.18 \\
\hline LMA-1 & 5 & 10,350 & 4980 & 9560 & 39,390 & 39,270 & 34,320 & 44,670 & 0.04 & -2.96 \\
\hline LMA-2 & 5 & 3430 & 1570 & 2580 & 35,860 & 35,210 & 34,110 & 37,540 & 0.30 & -2.76 \\
\hline LMA-3 & 5 & 3950 & 1610 & 1800 & 33,730 & 34,560 & 31,380 & 35,330 & -0.85 & -0.78 \\
\hline LMA-4 & 6 & 7600 & 2970 & 4810 & 30,620 & 29,960 & 27,750 & 35,350 & 0.81 & -0.45 \\
\hline LMA-5 & 5 & 7310 & 3130 & 2450 & 31,160 & 29,280 & 29,120 & 36,420 & 1.68 & 2.48 \\
\hline LMA-6 & 5 & 4450 & 1780 & 350 & 24,360 & 23,680 & 23,020 & 27,470 & 2.01 & 4.28 \\
\hline LMA-7 & 5 & 4950 & 1980 & 1950 & 25,310 & 24,500 & 23,440 & 28,390 & 1.14 & 0.63 \\
\hline LLA-1 & 4 & 9970 & 4660 & 6410 & 39,300 & 40,990 & 32,640 & 42,610 & -1.52 & 2.01 \\
\hline LLA-2 & 4 & 7800 & 3220 & 4500 & 32,840 & 32,790 & 29,000 & 36,800 & 0.10 & 0.83 \\
\hline LTA-1 & 3 & 2000 & 1120 & 2000 & 10,630 & 10,060 & 9910 & 11,920 & 1.70 & $\mathrm{n} / \mathrm{a}$ \\
\hline LTA-2 & 4 & 3470 & 1430 & 1840 & 11,380 & 11,550 & 9480 & 12,950 & -0.67 & 1.66 \\
\hline
\end{tabular}

Abbreviations: $n$ — number of shells; SD — standard deviation; IQ — inter-quartile range; MIN — minimum shell age; MAX — maximum shell age; $S$ - skewness of an age distribution; $K$ - kurtosis of an age distribution. 
those parameters computed from our real samples are then used to assess if the samples display more extensive time-averaging than expected under the null model. We used the percentile method (so called "naïve bootstrap" of Efron, 1981) to assess the significance of each parameter for each sample.

To make the tests appropriately conservative, a stringent Bonferroni correction was applied by dividing each estimated significance value $p$ by the total number of tests. Because samples were collected independently this highly conservative correction is appropriate, but makes it much harder to demonstrate the presence of real timeaveraging in our samples. A significance level alpha of 0.05 is assumed throughout all analyses.

\subsection{The concept of time-averaged age distributions}

Many biologists and paleontologists use the term "age distribution" or "age frequency distribution" to denote a demographic structure of a biological population. Thus, for example, a right-skewed age distribution denotes populations/fossil populations dominated by juveniles/ small fossils. However, in studies of time-averaging based on numerical dating of fossils, age distributions are used differently. The "shell age" denotes "the age-sincedeath" (i.e., how old is a given shell in terms of its age relative to the age of the fossil deposit), and not "the-ageat-death" (how old was the shell-producing organism when it died). Thus, a small juvenile that died 1000 years before the deposit was formed represents an "old shell", whereas a large mature specimen that died just one year before the shell-bearing sediment was buried represents a "young shell". In other words, the "age distributions" as used here are geochronological estimates that measure the age of specimens relative to age of deposits, but do not provide any insights into the internal dynamics of individual biological populations.

\section{Results and discussion}

When all dated specimens are pooled together, shells range in age from $\sim 2810$ to $\sim 57,430$ years (Table 4 ; Fig. 4A). The median shell age is $\sim 31,060$ years and the standard deviation (SD) is 13,120 years. The distribution is left skewed, with shells becoming increasingly less frequent in younger age classes (Fig. 4B). The age structure of pooled data reflects primarily stratigraphic distribution of sampled horizons and offers no direct insights into the scale and structure of time-averaging within individual horizons. These pooled results are shown here mainly to highlight the stratigraphic range represented by dated shells.

To evaluate the structure and scale of time-averaging (age mixing), individual samples of dated shells were analyzed separately for each stratigraphic horizon (Figs. 5, 6 and 7; Table 4). Most samples reveal a substantial variation in shell age, often exceeding the error expected given the precision of radiocarbon calibrated amino acid dating. The average shell age range is 6670 years, the average standard deviation is 2920 years, and the average inter-quartile range is 3730 years (Table 4). Individual age distributions vary greatly in terms of their dispersion, whether measured by standard deviation, range or inter-quartile range (Table 4). For example, the average standard deviation per sample (stratigraphic horizon) is $\sim 2920$ years, but it ranges from as much as $\sim 7200$ years in FAG-3 down to as little as $\sim 510$ years in FBE-7 (Table 5). This variation in scale of time-averaging is observed at all sampling scales: among islands, within island across sections, and between levels within the same sections (Table 4).

When the most conservative approach (non-sequential Bonferroni correction) is applied, Monte Carlo simulations (Table 6; Fig. 8) indicate that 11 out of 44 samples have standard deviations that exceed significantly the

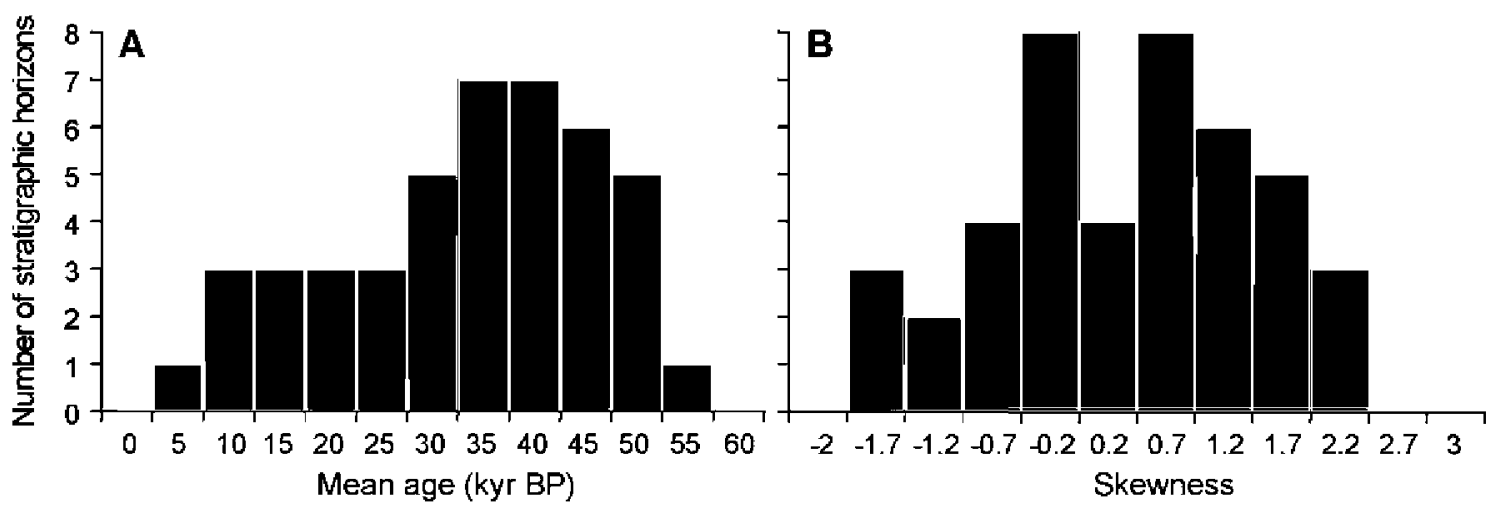

Fig. 4. Frequency distributions of sample-level mean shell age (A) and shell age skewness (B) for the 44 samples/horizons included in this study. 


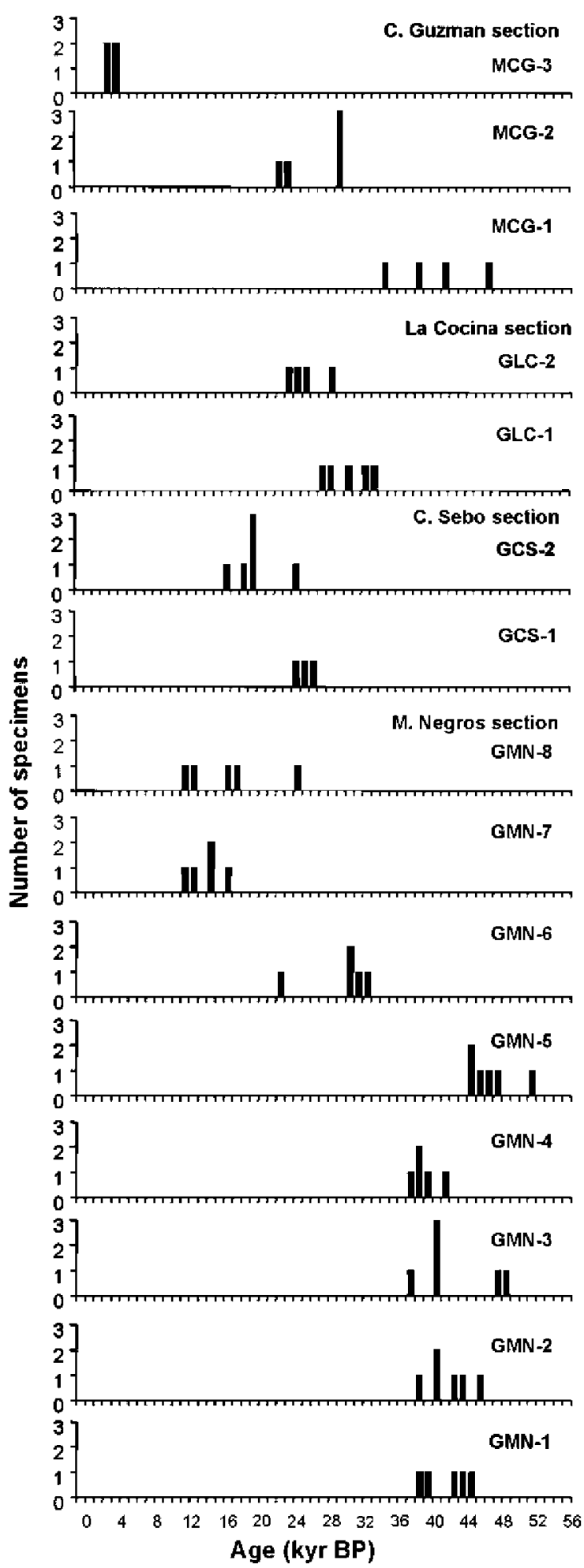

Fig. 5. Age-frequency distribution of shells plotted separately for each stratigraphic horizon from the La Graciosa, and Montaña Clara islets.

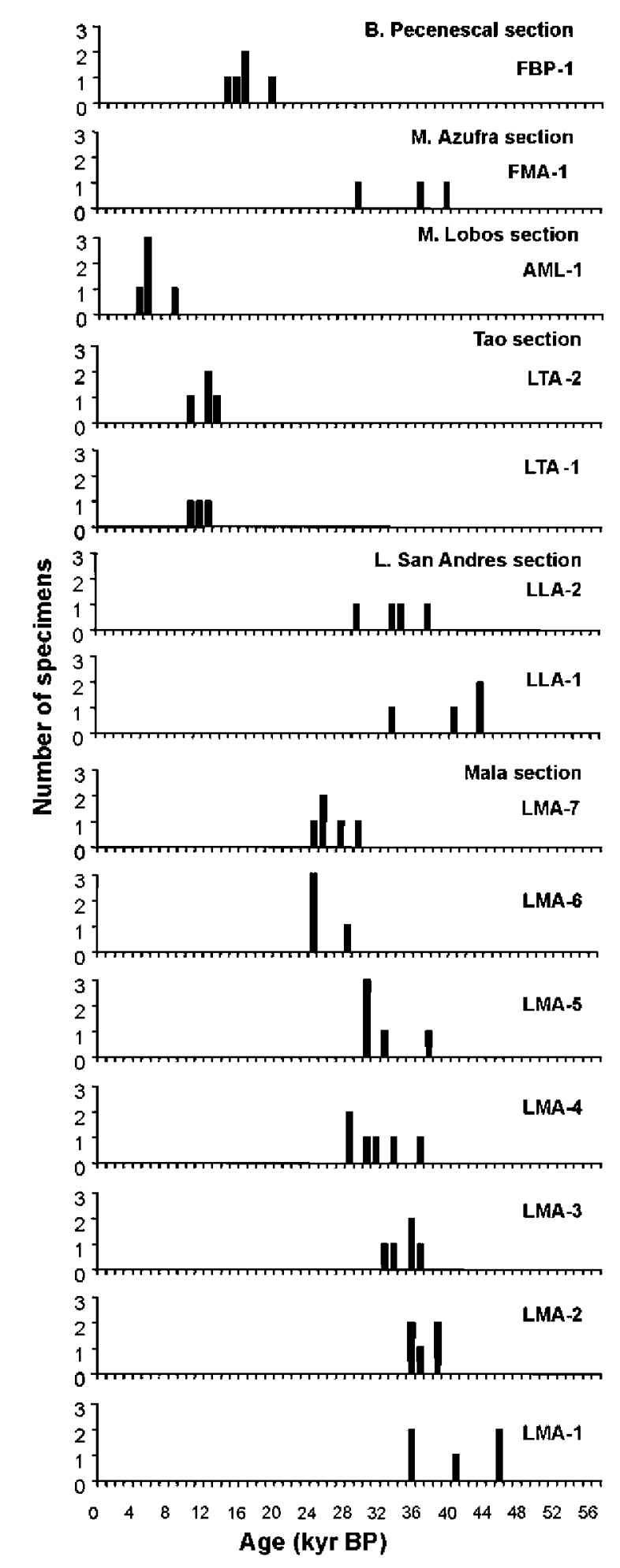

Fig. 6. Age-frequency distribution of shells plotted separately for each stratigraphic horizon from Alegranza Islet, Lanzarote Island and Fuerteventura Island. 


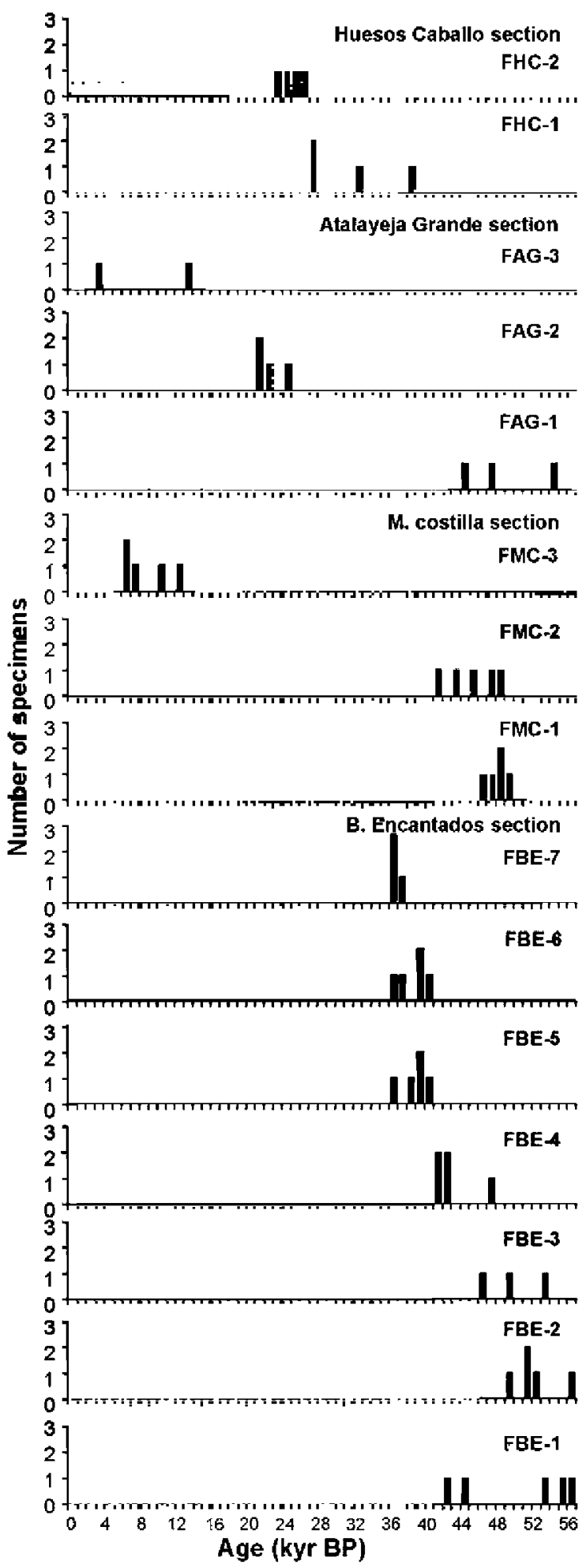

Fig. 7. Age-frequency distribution of shells plotted separately for each stratigraphic horizon from Fuerteventura Island. expected values due to dating imprecision statistically (other dispersion parameters yield consistent predictions in nearly all cases; see Table 6). That is, at least $25 \%$ of samples must have undergone substantial time-averaging. Moreover, in 30 out of 44 cases, observed standard deviations of the samples exceed the expected values predicted from dating errors (this ratio is significantly higher than the 50:50 ratio expected if time-averaging was due solely to dating errors only; $\chi^{2}=5.82, p=0.02$; Goodness of Fit Test).

The pervasive presence of time-averaging in many samples indicates that the observed age-mixing cannot be attributed to a diagenetic bias. First, only $\sim 5 \% \mathrm{spec}-$ imens in the study area are likely to be affected substantially by such bias (see Section 2.3 above), which is insufficient to explain the presence of age variations observed for multiple specimens in many samples. Second, elevated time-averaging is observed frequently also for the stratigraphically youngest samples, which are least likely to be affected by substantial diagenesis. Indeed, dispersions of age distributions and their shape parameters (skewness and kurtosis) do not show any notable correlations with the mean age of dated shells at a given horizon (Fig. 9). That is, the age structure and scale of mixing do not appear to be related to the age of the sampled horizon (Fig, 9).

The shape of age distributions of individual samples varies greatly, including both left skewed distribution (17 out of 44) with older age classes dominating as well as right skewed distributions (26 out of 44) with younger age classes dominated. Similarly, some distributions include a prominent modal age (high kurtosis), whereas others have platykurtic (less peaky than normal) age distributions. The presence of numerous left-skewed and platykurtic age distributions is intriguing because previous studies of time-averaging (focused on marine settings) indicated that shell age distributions tend to be right skewed with a strong (leptokurtic) mode (Flessa et al., 1993; Meldahl et al., 1997; Olszewski, 1999; Carroll et al., 2003; Kowalewski and Bambach, 2003;

Table 5

Summary of descriptive statistics averaged across all samples (stratigraphic horizon)

\begin{tabular}{llll}
\hline & Mean & Maximum & Minimum \\
\hline$n$ & 4.60 & 6 & 2 \\
Range (yr) & 6670 & 15,300 & 1140 \\
SD (yr) & 2920 & 7200 & 510 \\
IQ (yr) & 3730 & 10,920 & 350 \\
Skewness & 0.38 & 2.21 & -2.00 \\
Kurtosis & 0.49 & 4.93 & -3.12 \\
\hline \multicolumn{7}{l}{ Abbreviations: $n-$ number of shells; SD - standard deviation; IQ - } \\
inter-quartile range.
\end{tabular}


Table 6

Monte Carlo assessment of time averaging observed in the samples

\begin{tabular}{|c|c|c|c|c|c|c|c|c|c|c|c|c|c|}
\hline Horizon & $n$ & $\mathrm{SD}_{\mathrm{OBS}}$ & $\mathrm{SD}_{\mathrm{EXP}}$ & $p$ & IQ & $\mathrm{IQ}_{\mathrm{SLM}}$ & $p$ & $R_{\mathrm{OBS}}$ & $R_{\mathrm{SMM}}$ & $p$ & $S_{\mathrm{OBS}}$ & $S_{\mathrm{SIM}}$ & $p$ \\
\hline GMN-1 & 5 & $2560 \dagger$ & 2370 & 0.32400 & $3790 \dagger$ & 2340 & 0.14476 & $5940 \dagger$ & 5520 & 0.39123 & -0.486 & -0.002 & 0.69591 \\
\hline GMN-2 & 6 & 2350 & 2370 & 0.42316 & 2300 & 3040 & 0.66914 & $6730 \dagger$ & 6000 & 0.33712 & -0.037 & 0.000 & 0.51874 \\
\hline GMN-3 & 6 & $4300 \dagger$ & 2370 & $0.00586^{*}$ & $6990 \dagger$ & 3040 & $0.00807^{*}$ & $10,730 \dagger$ & 6010 & $0.01770^{*}$ & 0.717 & -0.001 & 0.19729 \\
\hline GMN-4 & 5 & 1640 & 2370 & 0.74888 & 760 & 2340 & 0.90341 & 4470 & 5510 & 0.66865 & 0.976 & 0.001 & 0.14928 \\
\hline GMN-5 & 6 & $2570 \dagger$ & 2370 & 0.31979 & 2420 & 3040 & 0.63414 & $7080 \uparrow$ & 6010 & 0.28170 & 1.468 & -0.001 & $0.04432^{*}$ \\
\hline GMN-6 & 5 & $4050 \dagger$ & 2370 & $0.01988^{*}$ & 1860 & 2360 & 0.58746 & $9740 \uparrow$ & 5510 & $0.03007^{*}$ & -2.003 & -0.004 & 0.99032 \\
\hline GMN-7 & 5 & $1930 \dagger$ & 400 & $0.00001^{* *}$ & $2750 \dagger$ & 400 & $0.00001^{\text {* } * 3}$ & $4590 \uparrow$ & 930 & $0.00001^{* *}$ & -0.250 & -0.004 & 0.59918 \\
\hline GMN-8 & 5 & $5170 \dagger$ & 400 & $0.00001^{* * *}$ & $5210 \dagger$ & 400 & $0.00001^{* * *}$ & $13,210 \dagger$ & 930 & $0.00001^{* * *}$ & 0.879 & -0.001 & 0.17113 \\
\hline GCS-1 & 3 & 1050 & 2370 & 0.81890 & 1960 & 4000 & 0.82565 & 1960 & 4000 & 0.82565 & -1.535 & 0.004 & 0.85032 \\
\hline GCS-2 & 6 & $2740 \dagger$ & 400 & $0.00001^{* *}$ & $950 \dagger$ & 510 & $0.04804 *$ & $8390 \dagger$ & 1010 & $0.00001 * *$ & 1.183 & 0.000 & 0.08447 \\
\hline GLC-1 & 5 & 2210 & 2370 & 0.48084 & $3480 \dagger$ & 2350 & 0.19407 & 5160 & 5520 & 0.53694 & -0.118 & -0.001 & 0.54888 \\
\hline GLC-2 & 4 & $2440 \dagger$ & 2370 & 0.36441 & $3500 \dagger$ & 3140 & 0.36249 & $5710 \dagger$ & 4880 & 0.32168 & 0.881 & -0.006 & 0.21716 \\
\hline MCG-1 & 4 & $5080 \dagger$ & 2370 & $0.00293^{*}$ & $7410 \dagger$ & 3150 & $0.00496^{*}$ & $11,970 \dagger$ & 4890 & $0.00195^{*}$ & 0.664 & -0.001 & 0.27210 \\
\hline MCG-2 & 5 & $3670 \dagger$ & 2370 & $0.04795^{*}$ & $6204 \uparrow$ & 2340 & $0.00976^{*}$ & $7210 \dagger$ & 5510 & 0.19703 & -0.643 & 0.002 & 0.76025 \\
\hline MCG-3 & 5 & $3950 \dagger$ & 400 & $0.00001^{* *}$ & $480 \dagger$ & 400 & 0.32018 & $9090 \dagger$ & 930 & $0.00001 * *$ & 2.216 & -0.001 & $0.00015^{\text {** }}$ \\
\hline AML-1 & 5 & $1410 \dagger$ & 400 & $0.00001^{* *}$ & $770 \dagger$ & 400 & 0.06803 & $3610 \uparrow$ & 930 & $0.00001 * *$ & 1.653 & 0.003 & $0.03971^{*}$ \\
\hline FBE-1 & 5 & $6800 \dagger$ & 2370 & $0.00002^{* * *}$ & $10,920 \dagger$ & 2350 & $0.00001^{* *}$ & $15,300 \dagger$ & 5520 & $0.00003 * *$ & -0.416 & 0.001 & 0.67018 \\
\hline FBE-2 & 5 & $3400 \dagger$ & 2370 & 0.08405 & 900 & 2350 & 0.86993 & $9070 \uparrow$ & 5520 & 0.05368 & 1.541 & -0.003 & 0.05261 \\
\hline FBE-3 & 3 & $3410 \dagger$ & 2370 & 0.12636 & $6820 \dagger$ & 4000 & 0.10528 & $6820 \uparrow$ & 4000 & 0.10528 & 0.211 & 0.008 & 0.46435 \\
\hline FBE-4 & 5 & $2520 \dagger$ & 2370 & 0.34028 & 1050 & 2340 & 0.82687 & $6070 \uparrow$ & 5510 & 0.36616 & 2.030 & 0.002 & $0.00785^{*}$ \\
\hline FBE-5 & 5 & 1190 & 2370 & 0.90591 & 730 & 2340 & 0.90858 & 3150 & 5510 & 0.87903 & -1.326 & 0.006 & 0.91798 \\
\hline FBE-6 & 5 & 1560 & 2370 & 0.78388 & 2020 & 2340 & 0.53642 & 3640 & 5510 & 0.81494 & -0.909 & -0.002 & 0.83447 \\
\hline FBE-7 & 4 & 510 & 2370 & 0.98716 & 800 & 3140 & 0.98224 & 1140 & 4870 & 0.98224 & 0.543 & -0.003 & 0.30088 \\
\hline FBP-1 & 5 & $1980 \dagger$ & 400 & $0.00001^{* *}$ & $1280 \dagger$ & 400 & $0.00142^{* *}$ & $5220 \dagger$ & 930 & $0.00001^{* *}$ & 1.298 & -0.001 & 0.08791 \\
\hline FMA-1 & 3 & $4970 \dagger$ & 2370 & $0.01265^{*}$ & $9610 \dagger$ & 4020 & $0.01182^{*}$ & $9610 \dagger$ & 4020 & $0.01182^{*}$ & -1.195 & 0.002 & 0.74461 \\
\hline FMC-1 & 5 & 1050 & 2370 & 0.94187 & 1620 & 2350 & 0.65861 & 2460 & 5520 & 0.94904 & -0.097 & -0.004 & 0.53811 \\
\hline FMC-2 & 5 & $2730 \dagger$ & 2370 & 0.25644 & $4000 \dagger$ & 2350 & 0.12267 & $6540 \dagger$ & 5520 & 0.29037 & -0.358 & -0.005 & 0.64412 \\
\hline FMC-3 & 5 & $2650 \dagger$ & 400 & $0.00001^{* *}$ & $3740 \dagger$ & 400 & $0.00001^{* *}$ & $6160 \uparrow$ & 930 & $0.00001 * *$ & 0.807 & 0.003 & 0.18951 \\
\hline FAG-1 & 3 & $5010^{\dagger}$ & 2370 & $0.01136^{*}$ & $9770 \dagger$ & 4000 & $0.00955^{*}$ & $9770 \dagger$ & 4000 & $0.00955^{*}$ & 1.053 & -0.001 & 0.29225 \\
\hline FAG-2 & 4 & 1150 & 2370 & 0.87130 & 1320 & 3140 & 0.92498 & 2490 & 4880 & 0.87843 & 1.874 & -0.001 & $0.02114^{*}$ \\
\hline FAG-3 & 2 & $7200 \dagger$ & 400 & $0.00001^{* *}$ & $10,180^{\dagger}$ & 450 & $0.00001^{* * *}$ & $10,180 \uparrow$ & 450 & $0.00001^{* *}$ & & & 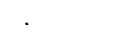 \\
\hline FHC-1 & 4 & $5310 \uparrow$ & 2370 & $0.00183^{*}$ & $8090 \dagger$ & 3140 & $0.00182^{*}$ & $11,470 \uparrow$ & 4880 & $0.00349^{*}$ & 1.023 & 0.003 & 0.18825 \\
\hline FHC-2 & 4 & 1580 & 2370 & 0.72204 & 2350 & 3150 & 0.68850 & 3750 & 4890 & 0.67853 & -0.135 & -0.001 & 0.56810 \\
\hline LMA-1 & 5 & $4980 \dagger$ & 2370 & $0.00153^{*}$ & $9560 \dagger$ & 2350 & $0.00010^{* * *}$ & $10,350 \uparrow$ & 5510 & $0.01791^{*}$ & 0.035 & -0.001 & 0.48353 \\
\hline LMA-2 & 5 & 1570 & 2370 & 0.78139 & $2580 \dagger$ & 2340 & 0.38017 & 3430 & 5510 & 0.84511 & 0.301 & -0.005 & 0.37655 \\
\hline LMA-3 & 5 & 1610 & 2370 & 0.76323 & 1800 & 2350 & 0.60456 & 3950 & 5520 & 0.76276 & -0.852 & 0.003 & 0.82090 \\
\hline LMA-4 & 6 & $2970 \dagger$ & 2370 & 0.16593 & $4810 \dagger$ & 3040 & 0.11362 & $7600 \dagger$ & 6010 & 0.20783 & 0.808 & 0.003 & 0.16941 \\
\hline LMA-5 & 5 & $3130 \dagger$ & 2370 & 0.13745 & $2450 \dagger$ & 2350 & 0.41527 & $7310 \dagger$ & 5510 & 0.18798 & 1.675 & 0.002 & $0.03746^{*}$ \\
\hline LMA-6 & 5 & 1780 & 2370 & 0.69092 & 350 & 2340 & 0.97560 & 4450 & 5510 & 0.67385 & 2.012 & -0.002 & $0.00902^{*}$ \\
\hline LMA-7 & 5 & 1980 & 2370 & 0.59287 & 1950 & 2340 & 0.55603 & 4950 & 5510 & 0.57618 & 1.143 & -0.001 & 0.11502 \\
\hline LLA-1 & 4 & $4660 \dagger$ & 2370 & $0.00891^{*}$ & $6410 \dagger$ & 3140 & $0.02032^{*}$ & $9970 \dagger$ & 4880 & $0.01538 *$ & -1.521 & -0.001 & 0.91550 \\
\hline LLA-2 & 4 & $3220 \dagger$ & 2370 & 0.13612 & $4500 \dagger$ & 3140 & $0.00291^{*}$ & $7800 \dagger$ & 4870 & 0.53289 & 0.099 & -0.004 & 0.44682 \\
\hline LTA-1 & 3 & $1120 \dagger$ & 400 & $0.00043^{* *}$ & $2000 \dagger$ & 670 & $0.00115^{*}$ & $2000 \uparrow$ & 670 & $0.00115^{*}$ & 1.697 & -0.005 & 0.06174 \\
\hline LTA-2 & 4 & $1430 \dagger$ & 400 & $0.00001^{* *}$ & $1840 \dagger$ & 530 & $0.00003^{* * *}$ & $3470 \uparrow$ & 820 & $0.00001^{* *}$ & -0.673 & 0.000 & 0.73095 \\
\hline
\end{tabular}

Separate simulations, 99,999 iterations each, were performed for each sample. The significance value $p$ was estimated as $k+1 / i+1$, where $k-$ number of simulated samples with parameter value equal to or greater than the observed value and $i$ - number of iterations (" +1 " in the nominator and denominator represent the actual sample; see Manly, 1991). Abbreviations: $n$ — number of dated shells; $p$ — significant level; SD $\mathrm{OBS}$ — standard deviation observed in a given sample; $\mathrm{SD}_{\mathrm{EXP}}$ - standard deviation predicted by the standard error of the radiocarbon calibrations; IQ $\mathrm{OBS}$ interquartile range observed in a given sample; IQ SIM $_{-}$mean interquartile range observed for simulated samples; $R_{\mathrm{OBs}}-$ range observed in a given sample; $R_{\mathrm{SIM}}$ - mean range observed for simulated samples; $S_{\mathrm{OBS}}$ - skewness observed in a given sample; $S_{\mathrm{SLM}}$ - mean skewness observed for simulated samples. Symbols: * Significant at $\alpha=0.05 ; * *$ Significant with Bonferroni correction: $\alpha_{\mathrm{b}}=\alpha / 44=0.001 ; \dagger$ Observed sample dispersion metric exceeds the dispersion expected due to dating imprecision.

Kidwell et al., 2005; but see Kowalewski et al., 1998 for possible examples of uniform age distributions). Such prevalent right-skewness is an expected consequence of a decay-like loss of older age cohorts predicted for time- averaged assemblages. The presence of many leftskewed samples documented here suggests that the terrestrial shell assemblages may not follow the pattern documented for marine systems. 


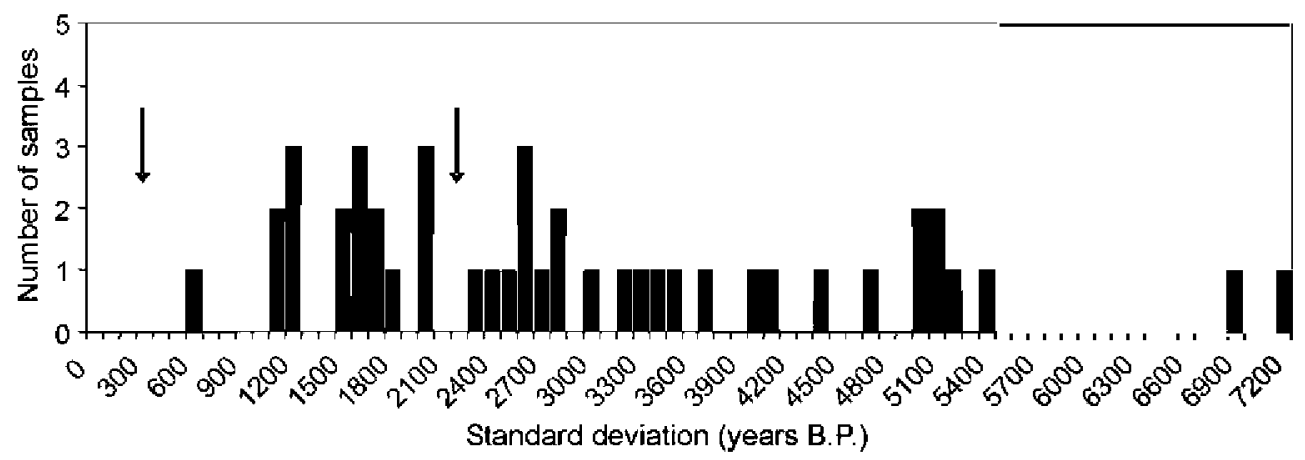

Fig. 8. Frequency distribution of standard deviations of samples. The two arrows indicate expected standard deviations that would be generated by dating imprecision alone. The expected standard deviations estimated separately for samples younger than 20 kyr (left arrow) and older than 20 kyr (right arrow).

However, this interpretation should be treated with caution when considering the sample sizes of individual samples (i.e., individual age distributions). When data are split by sample, the number of individually dated

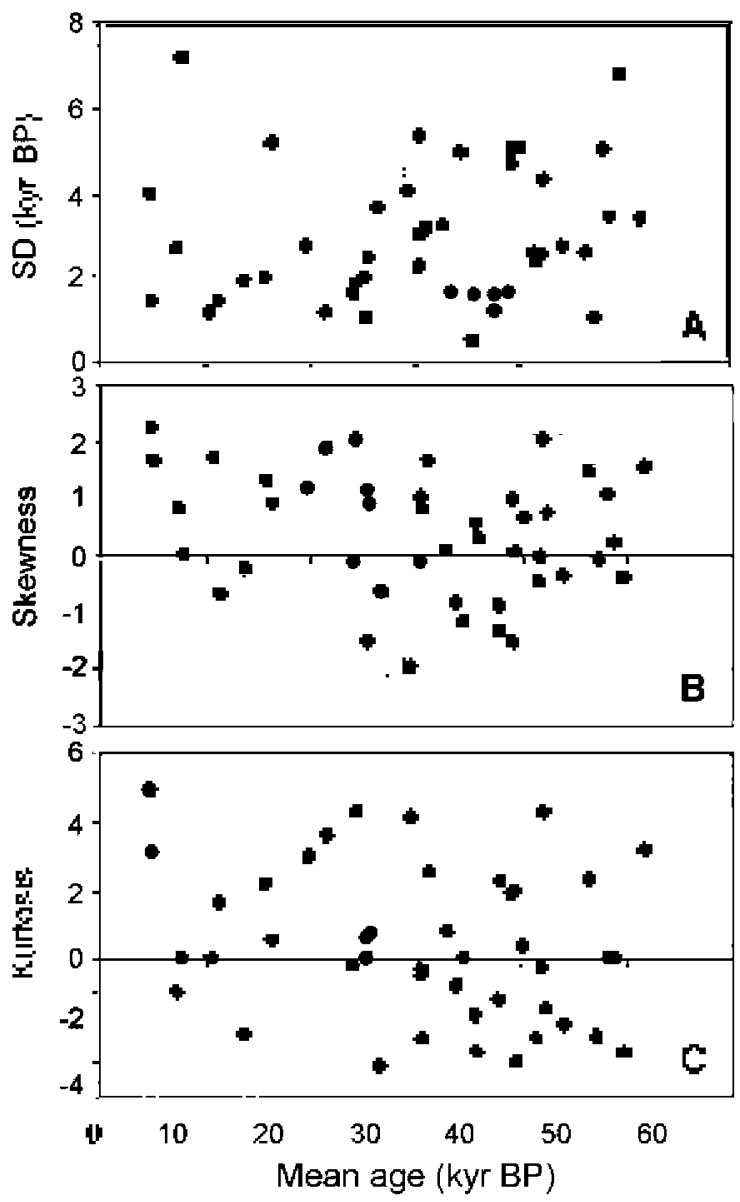

Fig. 9. Correlation between mean shell age in each sample (stratigraphic horizon) and the three age distribution parameters: standard deviation (A), skewiess (B), and kurtosis (C). specimens varies from 2 to 6 shells per sample: one sample includes 2 dated shells only, five include 3 shells only, nine include 4 shells, 24 include 5 shells, and finally, 5 samples include 6 shells (Table 4). Thus, the high variation in shape of age distributions may simply reflect volatility induced by small sample sizes. Similarly, the presence of left-skewed and/or platykurtic samples can be an artifact of small sample sizes. This caveat can be partly evaluated using a meta-analytical approach as follows. The data from marine systems suggest that the age distributions should be strongly right skewed. However, even if this is also true for terrestrial systems, when small samples of dated shells were to be drawn from such a right-skewed distribution some of them would still have appeared left skewed due to a sampling chance. However, when numerous small samples are taken, the right-skewed shapes should be much more frequent than the left-skewed ones. In the case of our data, the right skewed samples are indeed more common, but their dominance is moderate and insignificant: the observed ratio of right-skewed samples $(59 \%)$ is not significantly higher from the $\leq 50 \%$ ratio $\left(\chi^{2}=1.88, p=0.17\right.$; Goodness of Fit Test). Thus, the large number of left-skewed samples suggests a possibility that the age distributions of terrestrial shell accumulations need not be derived from a right-skewed distribution. This argument is inconclusive and indicates that future studies with larger sample sizes or larger number of samples are needed.

\section{Conclusions}

Most of the analyzed sets of samples show some level of age mixing. Such age mixing is expected given that dune and paleosol beds may form via somewhat prolonged accumulation, which may span hundreds to thousands of years (e.g., Retallack, 2001). Because 
individual dune beds are sealed by paleosols, reworking of shells from older levels into the younger ones is unlikely to have occurred.

For many samples the observed time-averaging exceeds significantly the scale of mixing that could be induced by the dating method imprecision. The lack of correlation between the standard deviation (and other parameters such as range and interquartile range) of individual samples and the average shell age (mostly reflecting the stratigraphic position of those samples) further supports the claim that the dating imprecision cannot be blamed on the observed age mixing. Note that if the dating imprecision was an important driver, samples dominated by older shells should have had an increased age variation because dating imprecision is expected to increase with the average shell age. The lack of correlation not only suggests that the scale of timeaveraging exceeds dating imprecision but also implies that the magnitude of temporal mixing has remained relatively constant through the studied time interval. This, in turn, indicates that the temporal dynamics of accumulation processes was similar among sampled horizons regardless of their stratigraphic position.

The statistically significant time-averaging on the order of thousands of years demonstrated here is consistent with previous studies for shelly organisms from other settings and regions: direct dating estimates from both terrestrial and marine environments (see Kowalewski and Bambach, 2003 for a summary of the literature), suggest that age mixing on the order of hundreds to thousands of years prevails in shell-rich accumulations.

Also, the results reported here confirm several previous dating projects conducted in other regions (Goodfriend, 1989; Cook et al., 1993; Goodfriend and Mitterer, 1993; Goodfriend et al., 1996; Meyrick and Preece, 2001; Brooke et al., 2003a,b; Hearty, 2003) showing that temporal mixing affects terrestrial gastropod shell accumulations found in eolian successions and other terrestrial environments. These results reinforce the importance of dating numerous specimens per horizon in geochronological studies (e.g., Goodfriend, 1989). That is, dating one or few specimens and using their age to estimate the age of the horizon may lead to a notable age overestimation, as many shells may be much older than the actual horizon.

The bulk of previous studies on the scale and structure of time-averaging focused on marine organisms. These studies revealed that, typically, time-averaged age distributions are right skewed (see above for references), a pattern attributed to exponential-like taphonomic loss of older age classes of shells (see especially Olszewski, 1999). Interestingly, a notable portion of our sam- ples displays left-skewed age distribution. As discussed above, this anomaly may reflect sampling deficiencies. Alternatively, this discrepancy may also indicate that taphonomic processes and time-averaging differ fundamentally between marine and terrestrial mollusk-rich accumulations.

\section{Acknowledgements}

Funding was obtained through the projects CGL200601586/BTE, from the Spanish Ministerio de Educación y Ciencia, and BOS2003/00374 from the Spanish Ministerio de Ciencia y Tecnología. We are indebted to Dr. Veronika Meyer of the University of Bern who helped in the setting up of The Biomolecular Stratigraphy Laboratory, which has been partially funded by ENRESA. Special thanks go to M. Ibáfíez, M.R. Alonso, M.L. Quesada, F. LaRoche, E. Martín-González, D. Liché and R.F. Armas (all from La Laguna University) for helping in sample collecting efforts. Additionally, we would like to thank Laurette Nordstrōm for helping in the X-ray diffraction analysis. We thank two anonymous reviewers for constructive reviews that greatly improved the quality of this report.

Alonso-Zarza, A.M., Silva, P.G., 2002. Quaternary laminar calcretes with bee nests: evidences of small-scale climatic fluctuations, eastern Canary Islands, Spain. Palaeogeography, Palaeoclimatology, Palaeoecology 178, 119-135.

Barbour Wood, S., Krause Jr., R.A., Kowalewski, M., Wehmiller, J.A., Simōes, M.G., 2006. Aspartic acid (Asp) racemization dating of Holocene calcitic brachiopods and aragonitic bivalves from the southern Brazilian Shelf, South Atlantic. Quaternary Research 66, 23-331.

Behrensmeyer, A.K., Kidwell, S.M., Gastaldo, R.A., 2000. Taphonomy and paleobiology. Paleobiology 26, 103-147.

Brooke, B.P., Murray-Wallace, C.V., Woodroffe, C.D., Heijnis, H., 2003a. Quaternary aminostratigraphy of eolianite on Lord Howe Island, southwest Pacific Ocean. Quaternary Science Reviews 22, $387-406$.

Brooke, B.P., Woodroffe, C.D., Murray-Wallace, C.V., Heijnis, H., Jones, B.G., 2003b. Quaternary calcarenite stratigraphy on Lord Howe Island, southwestern Pacific Ocean and the record of coastal carbonate deposition. Quaternary Science Reviews 22, 859-880.

Carroll, M., Kowalewski, M., Simoes, M.G., Goodfriend, G.A., 2003 Quantitative estimates of time-averaging in terebratulid brachiopod shell accumulations from a modern tropical shelf. Paleobiology $29,381-402$.

Castillo, C., Martín-González, E., Yanes, Y., Ibáñez, M., De la Nuez, J., Alonso, M.R., Quesada, M.L., 2002. Estudio preliminar de los depósitos dunares de los Islotes del Norte de Lanzarote Implicaciones paleoambientales. Geogaceta 32, 79-82.

Cohen, A.S., 1989. The taphonomy of gastropod shell accumulations in large lakes: an example from Lake Tanganyika. Paleobiology $15,26-45$. 
Cook, L.M., Goodfriend, G.A., Cameron, R.A.D., 1993. Changes in the land snail fauna of eastern Madeira during the Quaternary. Philosophical Transactions of the Royal Society of London. Series B, Biological Sciences 339, 83-103.

Cowie, R.H., 1984. The life-cycle and productivity of the land snail Theba pisana (Mollusca: Helicidae). Journal of Animal Ecology $53,311-325$

Csapò, J., Csapó-Kiss, Z., Csapó Jr., J., 1998. Use of amino acids for age determination in archaeometry. Trends in Analytical Chemistry $17,140-148$

Cummins, R.H., 1994. Taphonomic processes in modern freshwater molluscan death assemblages: implications for the freshwater fossil record. Palaeogeography, Palaeoclimatology, Palaeoecology $108,55-73$.

Cummins, R.H., Powell, E.N., Stanton Jr., R.J., Staff, G., 1986. The size-frequency distribution in paleoecology effects of taphonomic processes during formation of molluscan death assemblages in Texas Bays. Paleontology 29, 495-518.

De La Nuez, J., Quesada, M.L., Alonso, J.J., Castillo, C., Martín, E., 1997. Edad de los Islotes en función de los datos paleontológicos. In: De La Nuez, J., Quesada, M.L., Alonso, J.J. (Eds.), Los Volcanes de los Islotes al Norte de Lanzarote. Fundación César Manrique, Lanzarote, pp. 73-81.

Edwards, N., Meco, J., 2000. Morphology and palaeoenvironment of brood cells of Quaternary ground-nesting solitary bees (Hymenoptera, Apidae) from Fuerteventura, Canary Islands, Spain. Proceedings of the Geologists' Association 111, 173-183.

Efron, B., 1981. Nonparametric standard errors and confidence intervals. Canadian Journal of Statistics 9, 139-172

Ellis, W.N., Ellis-Adam, A.C., 1993. Fossil brood cells of solitary bees on Fuerteventura and Lanzarote, Canary Islands (Hymenoptera: Apoidea). Entomologische Berichten 53, 161-173.

Engel, M.H., Goodfriend, G.A., Qian, Y., Mackot, S.A., 1994. Indigeneity of organic matter in fossils: a test using stable isotope analysis of amino acid enantiomers in Quaternary mollusk shells. Proceedings of the National Academy of Sciences of the United States of America 91, 10475-10478.

Flessa, K.W., 1993. Time-averaging and temporal resolution in recent marine shelly faunas. In: Kidwell, S.A., Behrensmeyer, A. (Eds.), Taphonomic approaches to time resolution in fossil assemblages. Paleontological Society Short Courses in Paleontology, vol. 6. University of Tennessee, Knoxville, pp. 9-33.

Flessa, K.W., Cutler, A.H., Meldahl, K.H., 1993. Time and taphonomyquantitative estimates of time-averaging and stratigraphic disorder in a shallow marine habitat. Paleobiology 19, 266-286.

Fujiwara, O., Kamataki, T., Masuda, F., 2004. Sedimentological timeaveraging and C-14 dating of marine shells. Nuclear Instruments \& Methods in Physics Research. Section B, Beam Interactions with Materials and Atoms 223-224, 540-544.

Genise, J.F., Edwards, N., 2003. Ichnotaxonomy, origin, and paleoenvironment ofQuaternary insect cells from Fuerteventura, Canary Islands, Spain. Journal of Kansas Entomological Society 76, 320-327.

Gittenberger, E., Ripken, Th.E.J., 1987. The genus Theba (Mollusca: Gastropoda: Helicidae). Systematics and distribution. Zoologische Verhandelingen 241, 1-62.

Gittenberger, E., Ripken, Th.E.J., Bueno, M.L., 1992. The forgotten Theba species (Gastropoda, Pulmonata, Helicidae). In: Gittenberger, E., Goud, S.J. (Eds.), Proceedings in the 10th Malacological Congress, Edinburgh, pp. 145-151.

Goodfriend, G.A., 1987. Chronostratigraphic studies of sediments in the Negev Desert, using amino acid epimerization analysis of land snails shells. Quaternary Research 28, 374-392.
Goodfriend, G.A., 1989. Complementary use of amino-acid epimerization and radiocarbon analysis for dating of mixed-age fossil assemblages. Radiocarbon 31, 1041-1047.

Goodfriend, G.A., 1991. Patterns of racemization and epimerisation of aminoacids in land snails shells over the course of the Holocene. Geochimica et Cosmochimica Acta 55, 293-302.

Goodfriend, G.A., 1992a. Rapid racemization of aspartic acid in mollusk shells and potential for dating over recent centuries. Nature 357, 399-401.

Goodfriend, G.A., 1992b. The use of land snail shells in paleoenvironmental reconstruction. Quaternary Science Reviews 11, 665-685.

Goodfriend, G.A., Meyer, R.R., 1991. A comparative study of the kinetics of amino acid racemization/epimerization in fossil and modern mollusk shells. Geochimica et Cosmochimica Acta 55 3355-3367.

Goodfriend, G.A., Mitterer, R.M., 1993. A 45,000-yr record of a tropical lowland biota - the land snail fauna from cave sediments at Coco Ree, Jamaica. Geological Society of America Bulletin 105, 18-29.

Goodfriend, G.A., Cameron, R.A.D., Cook, L.M., 1994. Fossil evidence of recent human impact on the land snail fauna of Madeira. Journal of Biogeography 21, 309-320.

Goodfriend, G.A., Flessa, K.W., Kowalewski, M., 1995. Age distributions of shells in cheniers and the late Holocene environmental history of the Colorado River Delta. Geological Society of America Abstracts with Program 27, A373.

Goodfriend, G.A., Cameron, R.A.D., Cook, L.M., Courty, M.A., Fedoroff, N., Livett, E., Tallis, J., 1996. The Quaternary eolian sequency of Madeira: stratigraphy, chronology, and paleoenvironmental interpretation. Palaeogeography, Palaeoclimatology, Palaeoecology 120, 195-234.

Goodfriend, G.A., Flessa, K.W., Hare, P.E., 1997. Variation in amino acid epimerization rates and amino acid composition among shell layers in the bivalve Chione from the Gulf of California. Geochimica et Cosmochimica Acta 61, 1487-1493.

Goodwin, D.H., Flessa, K.W., Téllez-Duarte, M.A., Dettman, D.L., Schöne, B.R., Avila-Serrano, G.A., 2004. Detecting time-averaging and spatial mixing using oxygen isotope variation: a case study. Palaeogeography, Palaeoclimatology, Palaeoecology 205, 1-21.

Hammer, O., Harper, D.A.T., Ryan, P.D., 2001. PAST: Paleontological Statistics Software Package for Education and Data Analysis. Palaeontologia Electronica 4.

Hare, P.E., Mitterer, R.M., 1968. Laboratory stimulation of amino acid diagenesis in fossils. Carnegie Institution of Washington Yearbook $67,205-208$.

Hearty, P.J., 1997. Boulder deposits from large waves during the last interglaciation on north Eleuthera Island, Bahamas. Quaternary Research 48, 326-338.

Hearty, P.J., 2003. Stratigraphy and timing of eolianite deposition on Rottnest Island, Western Australia. Quaternary Research 60, 211-222.

Hearty, P.J., Vacher, H.L., Mitterer, R.M., 1992. Aminostratigraphy and ages of Pleistocene limestones of Bermuda. Geological Society of American Bulletin 104, 471-480.

Hearty, P.J., Olson, S.L., Kaufman, D.S., Edwards, R.L., Cheng, H., 2004. Stratigraphy and geochronology of pitfall accumulations in caves and fissures, Bermuda. Quaternary Science Reviews 23, $1151-1171$.

Kerney, M.P., Cameron, R.A.D., 1979. A field guide to the land snails of Britain and north-west Europe. Collins, London.

Kidwell, S.A., 1998. Time-averaging in the marine fossil record: overview of strategies and uncertainties. Geobios 30, 977-995.

Kidwell, S.A., Best, M.M.R., Kaufman, D.S., 2005. Taphonomic trade-offs in tropical marine death assemblages: differential time 
averaging, shell loss, and probable bias in siliciclastic vs. carbonate facies. Geology 33, 729-732.

Kowalewski, M., 1996. Time-averaging, overcompleteness, and the geological record. Journal of Geology 104, 317-326.

Kowalewski, M., Bambach, R.K., 2003. The limits of paleontological resolution. In: Harries, P.J. (Ed.), High resolution approaches in stratigraphic paleontology: topic in geobiology series, vol. 21 Plenum Press/Kluwer, New York, pp. 1-48.

Kowalewski, M., Goodfriend, G.A., Flessa, K.W., 1998. Highresolution estimates of temporal mixing within shell beds: the evils and virtues of time-averaging. Paleobiology 24, 287-304.

Manly, B.F.J., 1991. Randomization and Monte Carlo methods in biology. Chapman and Hall, London.

Martin, R.E., Wehmiller, J.F., Harris, M.S., Liddell, W.D., 1996 Comparative taphonomy of bivalves and foraminifera from Holocene tidal flat sediments, Bahia la Choya, Sonora, Mexico (northern Gulf of California): taphonomic grades and temporal resolution. Paleobiology 22, 80-90.

Meco, J., Petit-Maire, N., Fontugne, M., Shimmield, G., Ramos, A.J., 1997. The Quaternary deposits in Lanzarote and Fuerteventura (Eastern Canary Islands, Spain): an overview. In: Meco, J., PetitMaire, N. (Eds.), Climates of the past. Fuerteventura and Lanzarote, International Union of Geological Sciences. UNESCO, Las Palmas de Gran Canaria, pp. 123-136.

Meldahl, K.H., Flessa, K.W., Cutler, A.H., 1997. Time-averaging and postmortem skeletal survival in benthic fossil assemblages: quantitative comparisons among Holocene environments. Paleobiology 23 , 207-229.

Meyrick, R.A., Preece, R.C., 2001. Molluscan successions from two Holocene tufas near Northampton, English Midlands. Journal of Biogeography 28, 77-93.

Murray-Wallace, C.V., 1995. Aminostratigraphy of quaternary coastal sequences in southern Australia: an overview. Quaternary International 26, 69-86.

Olszewski, T., 1999. Taking advantage of time-averaging. Paleobiology $25,226-238$.

Ortiz, J.E., Torres, T., Julià, R., Delgado, A., Llamas, F.J., Soler, V., Delgado, J., 2004. Numerical dating algorithms of amino acid racemization ratios from continental ostracodes. Application to the Guadix-Baza Basin (southern Spain). Quaternary Science Reviews $23,717-730$.

Ortiz, J.E., Torres, T., Yanes, Y., Castillo, C., De la Nuez, J., Ibáñez, M., Alonso, M.R., 2006. Climatic cycles inferred from the aminostratigraphy and aminochronology of Quaternary dunes and palaeosols from the eastern islands of the Canary Archipelago. Journal of Quaternary Science 21, 287-306.

Pigati, J.S., Quade, J., Shahanan, T.M., Haynes Jr., C.V., 2004. Radiocarbon dating of minute gastropods and new constraints on the timing of late Quaternary spring-discharge deposits in southern Arizona, USA. Palaeogeography, Palaeoclimatology, Palaeoecology 204, 33-45.

Powell, E.N., Kraeuter, J.N., Ashton-Alcox, K.A., 2006. How long does oyster shell last on an oyster reef? Estuarine, Coastal and Shelf Science 69, 531-542.

Preece, R.C., Day, S.P., 1994. Comparison of Post-glacial molluscan and vegetational successions from a radiocarbondated tufa sequence in Oxfordshire. Journal of Biogeography 21, 463-478.

Retallack, G.J., 2001. Soils of the past. An introduction to paleopedology. Blackwell Science, Oxford

Torres, T., Llamas, J., Canoira, L., García-Alonso, P., García-Cortés, A., Mansilla, H., 1997. Amino acid chronology of the Lower Pleistocene deposits of Venta Micena (Orce, Granada, Andalusia, Spain). Organic Geochemistry 26, 85-97.

Torres, T., Llamas, J.F., Canoira, L., Coello, J.F., García-Alonso, P., Ortiz, J.E., 2000. Aminostratigraphy of two Pleistocene marine sequences from the Mediterranean coast of Spain: Cabo de Huertas (Alicante) and Garrucha (Almería). In: Goodfriend, G.A., Collins, M.J., Fogel, M.L., Macko, S.A., Wehmiller, J.F. (Eds.), Perspectives in Amino Acids and Protein Geochemistry. Oxford University Press, New York, pp. 263-278.

Wehmiller, J.F., Miller, G.H., 2000. Aminostratigraphic dating methods in Quaternary geology. In: Noller, J.S., Sowers, J.M., Lettis, W.R. (Eds.), Quaternary Geochronology, Methods and Applications. American Geophysical Union Reference Shelf, pp. $187-222$.

Wehmiller, J.F., York, L.L., Bart, M.L., 1995. Amino acid racemization geochronology of reworked Quaternary mollusks on U.S. Atlantic coast beaches: implications for chronostratigraphy, taphonomy, and coastal sediment transport. Marine Geology 124, 303-337.

Yanes, Y., Castillo, C., Alonso, M.R., Ibáñez, M., De la Nuez, J., Quesada, M.L., Martín-González, E., La Roche, F., Liché, D., Armas, R.F., 2004. Gasterópodos terrestres Cuaternarios del Archipiélago Chinijo, Islas Canarias. Vieraea 32, 123-134. 